\title{
Osteology of the cranium and Weberian apparatus of African catfish families (Teleostei: Ostariophysi: Siluriformes) with an assessment of genera from the Palaeogene of Africa
}

\author{
Alison M. Murray* and Robert B. Holmes
}

Department of Biological Sciences, University of Alberta, Edmonton, AB, T6G 2E9, Canada; ammurray@ualberta.ca, https://orcid.org/0000-0001-9648-2902; holmes1@ualberta.ca

Abstract: Although the vast majority of fossil catfish material is isolated elements such as fin spines, a number of fossil catfishes (Siluriformes) have been named based on articulated crania from Palaeogene formations of Africa. The fossil taxa from marine sediments have been assigned to the extant marine family Ariidae, or have been assumed to have washed into marine sediments from freshwater habitats. The ability to assess the relationships of these fossils without reference to the nature of the geological sediments may provide insight into the history of these families. Most of the taxonomic work on the 11 catfish families found in Africa has focused on soft-tissues or DNA, which is problematic for the fossil material. Here we provide osteological features to distinguish families of African catfishes; eight of the families that are likely to be found in fossiliferous deposits can be distinguished based on a combination of skull features including the morphology of the cranial fontanelle, mesethmoid, and dermal ornamentation. We reassess the familial placement of the Palaeogene catfishes. We find that $†$ Eomacrones wilsoni, from the Palaeocene of Nigeria, belongs in Bagridae s.s. This confirms that bagrids were in Africa much earlier than the Miocene. Because this catfish comes from Palaeocene marine sediments, the biogeographic history of Bagridae needs to be reassessed to consider marine dispersal in this taxon.

\section{INTRODUCTION}

Catfishes (Siluriformes) are well represented in African fossiliferous deposits of the Cenozoic. Catfish have relatively robust skeletons, with thick bones that stand up well to transportation and preserve well in various depositional environments compared to the skeletons of many other fishes. In addition, many elements of catfish skeletons are quite distinctive compared with many other fish taxa, allowing relatively easy identification of fossils at an ordinal level. Because of this, the fossil record of catfishes is particularly good. Vertebral centra, pectoral- and dorsal-fin spines and cranial fragments have been reported from many deposits, allowing us to document the presence of catfishes in a particular place at a particular time. Identification of fragmentary material as belonging to a specific family or lower taxonomic level is more difficult (e.g., Argyriou et al. 2014; Murray et al. 2010; Otero et al. 2015). Ornamentation of cranial elements is considered indicative of family or generic level (e.g., Otero et al. 2015; Stewart and Murray 2017). Dorsal and pectoral fin spines also may be diagnostic for a genus or family (e.g., Gayet and Van Neer 1990), but researchers have assigned the vast majority of isolated elements to the lowest taxonomic level possible (usually family or genus) and have not named them as new taxa. The few fragmentary elements that have been named as unique species are probably not diagnostic. In contrast, catfish specimens that are preserved in partial articulation, mostly three-dimensional crania, can be distinguished from one another and extant forms, and many of these have been described and named as unique species or genera (e.g., Stromer 1904; Peyer, 1928; Murray and Budney 2003; Otero et al. 2007; El-Sayed et al. 2017). Several named catfishes are known from Palaeogene deposits of Africa, in particular from Nigeria and Tanzania, as well as the Fayum Depression of Egypt. 
Murray \& Holmes - Cranial osteology of African catfishes

\section{Survey of Palaeogene African catfish}

Nigerian Palaeocene catfishes: White (1934) reported a

partial skull from Thanetian (uppermost Palaeocene) deposits of Sokoto, Nigeria that he first named $\uparrow$ Macronoides wilsoni, for its similarity to the extant bagrid catfish Macrones Duméril, 1856 [see Fricke et al. (2020) for the current status of this genus]. However, this generic name was preoccupied by the extant catfish subgenus Macrones (Macronoides) Hora, 1921 (both the generic and subgeneric name are no longer valid; see Fricke et al. 2020), and so White (1936) renamed the fossil taxon $\dagger$ Eomacrones wilsoni. This catfish was tentatively assigned to Bagridae (White 1934). White (1934) based his familial designation on the similarity of the Nigerian fossil to the extant Indian genus, therefore, it is likely this fossil genus would have been retained in Bagridae after the revisions to the family by Mo (1991). White (1934) considered these catfishes to be freshwater species because of their presumed relationship with Bagridae, despite the fact that they were found in association with marine elasmobranchs; he concluded that the deposits probably formed in a shallow, nearshore, likely estuarine environment.

Cappetta (1972) reported the same species from Palaeocene deposits of Sessao, on the border between Niger and Mali. He also considered $†$ Eomacrones wilsoni to be a bagrid catfish. From Sessao, spines and many more skulls that were more complete than the holotype were recovered (Cappetta 1972). Although Cappetta (1972) indicated that the Sassao catfish material would be the subject of a future study, it appears the material has not yet been published. Cappetta (1972) noted that the elasmobranch fishes from Sessao indicated a marine environment but he assumed the catfishes were freshwater forms that were washed into the marine deposits despite the lack of other indications of freshwater sedimentary input.

From the same uppermost Palaeocene Nigerian deposits that produced the holotype skull of $†$ Eomacrones wilsoni, White (1934) described two more species of catfish and, based on overall similarity, placed them both in a single genus as $\dagger$ Nigerium wurnoense and $\dagger N$. gadense; however, he considered the assignment of both species to the same genus as provisional, as the two clearly differed in details of the anatomy.

Nigerian and Malian Eocene catfishes: Longbottom (2010) described a third species of $†$ Nigerium, $\dagger N$. tamaguelense, from lower Eocene deposits of Mali, based on multiple specimens. These deposits are marine, or possibly brackish, but many elements show signs of transportation so these could have originated in fresh waters (Tapanila et al. 2008). Longbottom (2010) gave several synapomorphies for the genus and placed it in Claroteidae.

White (1926), based on isolated elements (fin spines and one nuchal plate), named three other species of catfishes from marine middle Eocene beds of Nigeria (Oshosun and Ameki). Longbottom (2010) noted that all of these ( $\dagger$ Arius hewardbelli, $\uparrow$ A. kitsoni, $\uparrow$ A. russi) should probably be considered nomina dubia. G.A. Frost, in an appendix to White's (1926) paper, named a further three species of catfishes based on otoliths. Longbottom (2010) also considered these ( $\dagger$ Arius africanus, $\dagger$ Arius angulatus and $\dagger$ Arius amekiensis - which Frost indicated with the generic name fOtolithus (Arius) named for otoliths) to be nomina dubia. We agree that the fragmentary spines are likely not diagnostic, but leave the otolith taxa for specialists to assess. Whether or not any of the spines represents an ariid catfish is doubtful. White (1926) compared his material to other incomplete fossil spines that had been attributed to Arius, and noted that in at least one case $(\dagger A$. russi $)$, this generic designation was uncertain.

$\dagger$ Eaglesomia eaglesomei (White, 1926) was named for two incomplete crania and two partial Weberian apparatuses also from the Nigerian localities Oshosun and Ameki. White (1926) originally placed his new species in the extant genus Chrysichthys Bleeker, 1858a, based on its strong similarity in shape and ornamentation to the extant Chrysichthys cranchii (Leach 1818). Peyer (1928) reviewed much of the fossil record of catfishes known up to that point, and noted that White (1926) gave little anatomical detail to support placing his new species in Chrysichthys. In the appendix of a later paper, White (1934) noted that with the publication by Peyer (1928) of the Egyptian fossil catfish †Socnopaea (see below), the Nigerian material could be reassessed; White felt that it was more similar to the Egyptian fossil catfish than the extant Chrysichthys, and thus removed the Nigerian fossil to a new genus, $\dagger$ Eaglesomia, and provided a much more detailed description of the material. $\dagger$ Eaglesomia eaglesomei was placed in Bagridae by White (1926) and considered to be of a bagroid morphology (White 1934); however, Chrysichthys is now in the family Claroteidae, following revision of the bagrids by Mo (1991) and so it is the claroteids to which $\dagger$ Eaglesomia should likely be compared. However, Longbottom (2010) noted that $†$ Eaglesomia lacks several features that are found in Claroteidae, and she indicated it should not be included in that family.

Tanzanian Eocene catfish: A claroteid catfish, $\dagger$ Chrysichthys mahengeensis Murray and Budney, 2003, was reported from the mid-Eocene locality of Mahenge, Tanzania, which represents a freshwater crater lake. Unlike most other African taxa, this material comprises an articulated skeleton preserved in situ in the matrix (Murray and Budney 2003), rather than as an isolated, 3-dimensional cranium. As Longbottom (2010) noted, this makes comparison of the differently preserved material more difficult. Murray and Budney (2003) assigned the Tanzanian material to the 
extant genus Chrysichthys based on the presence of both dorsal and pectoral fin spines, a short anal fin not confluent with the caudal fin, and preserved soft tissue anatomy (presence of nasal barbels), as well as the ornamentation of the skull. As they noted, it is possible that this specimen represents a new genus of catfish, but they placed it in the extant genus Chrysichthys to highlight the affinities of the fossil species with the modern species.

Eocene catfishes from Fayum, Egypt: Catfish fossils were first reported from deposits of the Fayum Depression by Stromer (1904). Additional descriptions of this material was provided by Peyer (1928). Three genera with four species were named for catfish crania and other material recovered from the Eocene marine Qasr-el-Sagha Formation, $\dagger$ Socnopaea grandis Stromer, 1904, $\uparrow$ Fajumia schweinfurthi Stromer, 1904, $\dagger F$. stromeri Peyer, 1928 and $\dagger$ Eopeyeria aegyptiacus (Peyer, 1928). $\dagger$ Arius frassi Peyer, 1928 is from Eocene deposits at Mokattam.

The material of $\uparrow$ Socnopaea grandis examined by Stromer (1904) includes an incomplete, but quite large, skull that he considered might be related to one or more species of Bagridae, although he expressed some reservations. Peyer (1928) gave a much more detailed description of this species, and suggested it might be closer to the ariids. However, Longbottom (2010) noted that $†$ Socnopaea does not have the complex vertebra of the Weberian apparatus fused with the basioccipital as found in Arius, thus excluding it from Ariidae.

$\dagger$ Fajumia schweinfurthi Stromer, 1904 was named for five skulls, all about $25 \mathrm{~cm}$ long, from the Fayum. Peyer (1928) later described a second species, $\dagger F$. stromeri, that differs from $\dagger F$ schweinfurth $i$ in the shape of the skull, as well as the parieto-supraoccipital being slightly arched in $\dagger F$. stromeri, but bearing a median ridge on its dorsal surface in $\dagger F$. schweinfurthi. Stromer (1904) indicated that among the catfishes he compared it to, $\dagger F$ schweinfurthi shared most with extant pimelodid catfishes, a family found in Neotropical fresh waters; however, Peyer (1928) suggested that $\dagger$ Fajumia might be allied with the bagrids.

$\dagger$ Ariopsis aegyptiacus was named by Peyer (1928) for an articulated skull from Eocene deposits north of Fayum. $\dagger$ Ariopsis Peyer, 1928 is preoccupied by the extant catfish Ariopsis Gill, 1861. Whitley (1940) suggested the replacement name $\dagger$ Peyeria for this taxon, but this name is also preoccupied, by $\dagger$ Peyeria Weiler, 1935 (a fossil sawfish), so Whitley (1947) changed the fossil catfish genus to $\dagger$ Eopeyeria. The Fayum catfish skull is therefore $†$ Eopeyeria aegyptiacus (Peyer, 1928). The original generic name presumably indicated that Peyer (1928) saw similarities between the fossil skull and ariid catfishes.

$\dagger$ Arius fraasi Peyer, 1928 was also named for Eocene Egyptian material, but in this case the fossils were recovered from near Mokattam, roughly $100 \mathrm{~km}$ NNE of the Fayum Depression. $\dagger$ Arius frassi is from shallow marine deposits, and was considered to share a number of anatomical features with the extant genus Arius (Ariidae).

Two catfishes have been more recently described from the Fayum. The first, based on an articulated skull, is $\dagger$ Qarmoutus hitanensis El-Sayed et al., 2017 which was placed in the marine family Ariidae. This catfish is from the Birket Qarun Formation, which underlies, and is older than, the Qasr-el-Sagha Formation but is also of Eocene age. The second catfish is from an uppermost Eocene locality in the freshwater Jbel Qatrani Formation that we recently described as a new species of the extant genus Clarotes, as $\dagger$ Clarotes eocenicus, in the family Claroteidae (Murray and Holmes 2021).

Most of the catfishes described from Eocene deposits of Egypt are in need of revision. Their relationships as originally described many decades ago may not be correct. For example, Longbottom (2010) noted that $†$ Fajumia cannot belong to the family Ariidae, as it has an open aortic groove on the complex vertebra, whereas the aortic canal is enclosed in a tunnel in Ariidae. In addition to their relationships, these fossil catfishes also need to be reassessed in light of their presumed marine or freshwater affinities (see Discussion).

\section{Goal of this study}

All named Palaeogene fossil siluriforms from Africa have been assigned to extant families (e.g., van der Laan 2018), but the lack of documented osteological features to identify extant families of African catfishes hampers our understanding of the fossil diversity. In order to assign fossil crania and other isolated elements to families, we need to recognize features (not necessarily synapomorphies) that diagnose known families. It is only after eliminating membership of the fossils in all extant families that we can assign them to an extinct family. Therefore, in this paper we have undertaken to collate and evaluate previously identified features with our own observations of extant catfish that will either allow fossil crania to be attributed to extant families, or necessitate the erection of new families to accommodate these fossils. This work allows us to assess previously named African fossil catfishes to determine if their reported familial designations are supported.

\section{MATERIALS AND METHODS}

Material examined: Recent catfish material (Appendix 1) is housed in the collections of Cornell University, Ithaca, New York, USA (designated by CU), the Royal Ontario Museum, Toronto, Ontario, Canada (ROM), University of Alberta Museum of Zoology, Edmonton, Alberta, Canada (UAMZ), and the University of Michigan Museum of Zoology, Ann Arbor, Michigan, USA (UMMZ). Fossil 
material (Appendix 1) is from the collections of the Duke University Primate Center, Durham, North Carolina, USA (DPC) and Natural History Museum, London, UK (NHMUK P). The dagger symbol $(\dagger)$ is used throughout to indicate taxa that are wholly extinct. Name authorities and spellings for families are from van der Laan et al. (2014). Some features were not visible in our borrowed material of Schilbe in which the skeletons are still articulated; therefore, we augmented our observations with published descriptions for schilbeids by de Vos (1995). Similarly, we relied on Marceniuk et al. (2012) for information of a greater diversity of ariids, particularly African genera, than specimens available to us, and we corroborated our observations on Malapterurus with those published by Mahy (1974).

Material was photographed with an Olympus EM 10II OMD digital camera, and drawings were made (by RBH) using a camera lucida attachment on a Wild M5 microscope (for smaller specimens) or from photographs with reference to the original material (for larger specimens). The views for the specimens vary depending on the manner of articulation of the specimen; for example, there is no ventral view of the skull provided for specimens in which the branchial apparatus is still attached to the skull, and some lateral views of the skull include parts of the suspensorium, opercular series, and cleithrum because they are preserved attached to the specimen. Terminology for bones in catfish is not agreed upon, with different authors using different terms for elements depending on developmental studies and ideas of evolution and homology. We here arbitrarily follow the terminology of Marceniuk and Menezes (2007) with additions from Wright (2017) for clariids. Our use of this terminology does not indicate any opinion on the homology or development of any elements.

Abbreviations used in figures: aa, anguloarticular; a.c, aortic canal; a.t, aortic tunnel; bb, basibranchial; b.c, bony capsule of swimbladder; b.f, ventral fossa of basioccipital; boc, basioccipital; brst, branchiostegal rays; cc, compound centrum; ch, anterior ceratohyal; cl, cleithrum; cr.f, cranial fontalle; den, dentary; d.pt, dorsal-fin pterygiophore; d.sp, dorsal-fin spine; e.b, epiphyseal bar; ept, ento-ectopterygoid; epi, epioccipital; es, extrascapular; exo, exoccipital; fen, fenestra between lateral ethmoid and frontal; fr, frontal; hh, hypohyal; hyo, hyomandibula; ih, interhyal; io, infraorbital; iop, interopercle; lac, lacrimal (first infraorbital); leth, lateral ethmoid; met, metapterygoid; meth, mesethmoid; mx, maxilla; na, nasal; n.c, neural complex of Weberian apparatus; nu, nuchal plate; op, opercle; orb, orbitosphenoid; os.s, os suspensorium; pal, palatine; pa-soc, parieto-supraoccipital; p.ch, posterior ceratohyal; pop, preopercle; pp.v4, parapophysis of the fourth vertebra; pp.v5, parapophysis of the fifth vertebra; pro, prootic; psph, parasphenoid; p.sp, pectoral-fin spine; pto, pterotic; ptsph, pterosphenoid; ptt, posttemporal-supracleithrum; pv, prevomer; s, sesamoid bone; soc, supraoccipital crest; sph, sphenotic; spop, suprapreopercle; t, tripus; tr.t, transformator of tripus; v5 (v6), fifth (sixth) vertebral centrum; vo, vomer; vo.tth, vomerine teeth on separate or partially separate dental plate; v.pr.b, paired posteroventral processes on basioccipital.

\section{OVERVIEW OF AFRICAN CATFISH FAMILIES}

A complete assessment of all siluriform families is well beyond the scope of any single paper, and is part of a major ongoing collaboration among researchers throughout the world (All Catfish Species Inventory; http://silurus. acnatsci.org/). Here, we limit ourselves to a discussion of the African families, and of those, we concentrate on the ones that are most likely to be found in fossiliferous deposits. The goal of this section is to identify and describe features of the skull and Weberian apparatus (the most commonly fossilized diagnostic components) that are of potential use in the familial placement of fossil catfish. Many synapomorphies of extant catfish families are characters of the soft anatomy, which are unlikely, or only very rarely, to be preserved in fossil material (e.g., Murray and Budney 2003; Longbottom 2010). For this reason, it is often difficult to attribute fossil taxa to extant families. However, other features, not necessarily synapomorphies, may allow some fossil catfish material to be placed in particular families. Some of these features have been presented previously by other researchers and a number of features were found in the course of this work. We have not limited ourselves to synapomorphies, as our goal is to assign African fossil material to family, not to determine interfamilial relationships. With our focus on fossils, we concentrate on catfish remains that are commonly found in the fossil record, in particular articulated crania, Weberian apparatuses, and distinct cranial bones. Dorsal and pectoral fin spines, probably the most commonly reported catfish elements in the African fossil record, are excluded from this study, as they previously were reviewed in comparative studies by Gayet and Van Neer (1990) and Ballen and de Pinna (2021).

There are 39 extant families of catfishes globally (van der Laan et al. 2014) and an additional five extinct families (van der Laan 2018). Of these, ten of the extant and none of the extinct families are recorded as present in African waters (Diogo 2005; Seegers 2008). One additional family recorded as African by Seegers (2008) is Anchariidae Glaw and Vences, 1994 containing only two genera, Ancharius Steindachner, 1880 and Gogo Ng and Sparks, 2005. Anchariids are euryhaline species found in coastal rivers on 
the east coast of Madagascar and may be sistergroup to the marine ariids (Glaw and Vences 1994; Diogo 2005). This family is endemic to Madagascar ( $\mathrm{Ng}$ and Sparks 2005) and, although Madagascar may be considered part of the African region today, in terms of geological history, it has not shared a connection with the African continent since the Late Jurassic. The oldest records of Siluriformes are from Late Cretaceous deposits of South America (Arratia and Cione 1996; Gayet and Meunier 2003). Prior to the Cretaceous, Madagascar was sandwiched between southeastern Africa and India in Gondwana (e.g., Smith et al. 1994). It retained a connection to India during the break-up of Gondwana, but lost its connection with Africa about 160 million years ago as it rafted with India northeastwards (e.g., Pratt et al. 2017). No Palaeogene vertebrates, including catfish, have been found in Madagascar (Samonds et al. 2012), but if freshwater catfish were present, they are unlikely to be related to the Paleogene catfish of Africa because of the long separation of the two land masses. We do not have any anchariid specimens, so that family is excluded here, but we believe anchariids, being near-coastal and eastern Madagascan, are less likely to be found in African deposits.

The ten siluriform families represented in Africa (Diogo 2005; Seegers 2008) are Amphiliidae, Ariidae, Austroglanididae, Bagridae, Clariidae, Claroteidae, Malapteruridae, Mochokidae, Plotosidae, and Schilbeidae. Species of Ariidae and Plotosidae are predominantly marine, with a few species entering brackish and freshwaters. Only marine species of Plotosidae have been recorded for Africa, although some ariids are found in African fresh waters (Seegers 2008). Marine catfish species generally are confined to near-shore areas (Diogo 2005); the other African families generally are confined to fresh waters. Not all of the ten African catfish families have the same preservational potential, and so remains of some are less likely to be found, and indeed, not all of them have been reported in fossiliferous deposits. Fishes restricted to southern Africa (e.g., Austroglanididae) are also less likely to be preserved in the fossil record because there are few Cretaceous and Cenozoic deposits south of $10^{\circ} \mathrm{S}$ in Africa (Murray 2000; Moore et al. 2009). The age of fossiliferous deposits potentially may allow the researcher to narrow down the identity of the fossils, because some taxa (e.g., Clariidae) likely originated in Eurasia and were unable to enter Africa until after the continents were connected, allowing terrestrial (and freshwater) taxa to invade Africa in the Miocene (e.g., Stewart and Murray 2017). Of course, caution must be exercised before eliminating particular families from possible identities based on age of deposits to avoid circular reasoning: if one assumes a particular taxon cannot be present prior to the Miocene, then it would not be possible to identify remains to that family and thus confirm it was not present prior to the continents being connected to one another. Therefore, we have not excluded discussion of any African family based on age or possibility of preservation. However, extant members of two families (Amphiliidae and Austroglanididae) are all small, of low diversity, and restricted in habitat and/or distribution (see below), and so are unlikely to be found in African fossiliferous deposits. If extinct members of these families exhibited similar characteristics, the probability of preservation in African fossiliferous deposits is extremely low. A few features of these two families are noted in the section on features below, but they are not included in Table 1 because members of these two are not likely to be found in fossil collections and we do not have access to specimens.

Amphiliidae Regan, 1911: Amphiliidae contains 13 genera with 102 species (Fricke et al. 2020); these are known as mountain catfishes or loach catfishes (Skelton 2007) and are found only in Africa. Extant amphiliids are benthic fishes generally restricted to streams and rivers in higher altitudes, but fairly broadly distributed in western equatorial, central southern, and East Africa (Walsh et al. 2000). The extant species are small, with most not reaching $12 \mathrm{~cm}$ length, and having a maximum reported standard length of $20 \mathrm{~cm}$ (Skelton 2007; Nelson et al. 2016). Because of their relatively small size, higher-altitude-restricted range, and preference for rocky habitats (Walsh et al. 2000), amphiliids are less likely than other African catfishes to be preserved in fossiliferous deposits. None have been reported from the fossil record. They are here noted but not considered likely to be found in Palaeogene deposits of Africa. One species of Amphiliidae, Phractura brevicauda Boulenger, 1911, has been figured by Diogo et al. (2000) and modified from that publication by Arratia (2003:fig. 1.3A). Additional amphiliids are described and illustrated by Diogo (2003, 2005).

Austroglanididae Mo, 1991: Austroglanididae has only one genus, Austroglanis Skelton, Risch and Vos, 1984. Previously, this genus was placed in the Bagridae from which it was removed by Mo (1991). There are three extant species, all endemic to South Africa (Mo 1991). Because of their restricted distribution and the lack of Palaeogene deposits in southern Africa these catfishes are not likely to be found in fossiliferous deposits. We do not include any austroglanidids here.

Ariidae Bleeker, 1858b: Ariidae is a large family with about 30 genera and 150 species (Nelson et al. 2016). Ariid catfishes are found world-wide in marine waters and several species are found in brackish and fresh waters, with some penetrating far upriver (e.g., Marceniuk et al. 2012). Eleven species are found in coastal waters of Africa not including Madagascar (Seegers 2008). There is great variety in body size and form among ariids, and the family has been the 
Murray \& Holmes - Cranial osteology of African catfishes

subject of several revisions. Here we follow the phylogeny and taxonomy of Marceniuk et al. (2012). Most African ariids (except species of Galeichthys Valenciennes in Cuvier and Valenciennes, 1840) are represented by members of the well-supported monophyletic 'Ariinae - Old World' clade of Betancur-R (2009:fig. 3). However, the ariid genera currently found in African coastal waters (in addition to Galeichthys these are Arius Valenciennes in Cuvier and Valenciennes, 1840, Carlarias Marceniuk and Menezes, 2007, Netuma Bleeker, 1858a and Plicofolis Kailola, 2004) are not closely related to one another within that group according to the cladograms of Betancur-R (2009) and Marceniuk et al. (2012).

Ariidae has been reported from a number of African fossil deposits, and several taxa named for African fossils have been assigned to this family. These fossil forms are reassessed below. We use Ariopsis felis (Linnaeus, 1766) as a representative for this family (Fig. 1), with additional information on other species from the literature, in particular Marceniuk and Menezes (2007).

Bagridae Bleeker, 1858b: The family Bagridae, found in Asia and Africa, was redefined by Mo (1991) and now the only representative of the family in Africa is the genus Bagrus Bosc, 1816. The other African genera that were formerly in the family are now assigned to the families Austroglanididae, Amphiliidae and Claroteidae (Mo 1991). There are ten species of Bagrus, all found in Africa; an eleventh species has been placed in Bagrus, but this is a catfish from fresh waters of Argentina (Fricke et al. 2020; Froese and Pauly, 2020) and so is unlikely to be correctly placed in this genus or family. We use Bagrus docmac (Fabricius in Niebuhr, 1775) and B. bajad (Fabricius in Niebuhr, 1775) as representatives for this family (Fig. 2).

Clariidae Bonaparte, 1845: Members of Clariidae (walking catfishes) have an accessory breathing apparatus that allows them to survive periods out of water and also to inhabit poor-quality waters. Clariids are found in Africa and Asia, with the African forms represented by 13 genera (Seegers 2008). According to Seegers (2008), four of these 13 genera are endemic to a single lake (Bathyclarias Jackson, 1959 in Lake Malawi, Dinotopterus Boulenger, 1906 and Tanganikallabes Poll, 1943 in Lake Tanganyika, Xenoclarias Greenwood, 1958 in Lake Victoria), one is endemic to a restricted habitat (Uegitglanis Gianferrari, 1923 in caves and subterranean habitats of Somalia), and six are found in the Congo River or water bodies of West and south-central Africa (Channallabes Günther, 1873 [this is considered by some to be a subgenus of Gymnallabes], Clariallabes Boulenger, 1900, Dolichallabes Poll, 1942, Gymnallabes Günther, 1867, Platyallabes Poll, 1977, and Platyclarias Poll, 1977). Only two genera are found throughout Africa, Clarias Scopoli, 1777 (also found in southern Asia), and
Heterobranchus Geoffroy St. Hilaire, 1809 (pan-African but not found in most of East Africa). The distribution of these genera, with only the last two being common in North and East Africa (from which areas most fossils come), is likely why fossil clariid remains identified to genus are almost always attributed to these two genera (e.g., Stewart 2001). We use Clarias gariepinus (Burchell, 1822) as a representative for this family (Fig. 3).

Claroteidae Bleeker, 1862: Claroteidae contains a number of species removed from Bagridae by Mo (1991). However, it was de Pinna (1998) who united claroteids with the Auchenoglanididae, and thus formed two subfamilies, both of which are found only in African fresh waters (Froese and Pauly 2020). Although there are 14 genera included in the family, fossil material has only been reported as belonging to three genera, Chrysichthys Bleeker, 1858a, Clarotes Kner, 1855 and Auchenoglanis Günther, 1865 (Stewart 2001; Otero et al. 2007); these are the only three genera of the family found in the Nile River or waters of East Africa that are not endemic to lakes (e.g., Lake Tanganyika) or have very limited distributions, with most claroteid genera found in West Africa (see Seegers 2008). We use Chrysichthys auratus (Geoffroy St. Hilaire, 1827) (Fig. 4), Clarotes laticeps (Rüppell, 1829) (Figs. 5, 6) and Auchenoglanis occidentalis (Valenciennes in Cuvier and Valenciennes, 1840) (Figs. 7, 8) as representatives for this family.

Malapteruridae Bleeker, 1858b: The electric catfishes, capable of stunning prey with a discharge from their electric organs, are members of the Malapteruridae. This family contains 21 species grouped into two genera, Malapterurus Lacepède, 1803 and Paradoxoglanis Norris, 2002, that are endemic to fresh waters of Africa (Norris 2002). The family was revised by Norris (2002) and he described a number of new species, most of which are still recognized as valid. The relationships of Malapteruridae are not well understood, but the family appears to be close to the Mochokidae among African families (Diogo, 2005), or Mochokidae + Amphilidae (Sullivan et al. 2006:fig. 2). Malapteruridae has a limited fossil record with only a tentative report from Plio-Pleistocene deposits of Africa (Stewart, 2001). We use Malapterurus electricus (Gmelin, 1789) as a representative for this family (Figs. 9, 10), with reference to Mahy (1974) for information on additional species.

Mochokidae Regan, 1912: The squeaker catfishes, family Mochokidae, are found only in Africa, but are very diverse, with 11 genera and 222 species (Seegers 2008; Fricke et al. 2020). Despite the diversity, all fossils except one have been assigned to the genus Synodontis Cuvier, 1816. This may be because the distribution of some genera does not overlap with fossil deposits or the genera contain smaller taxa that are less likely to be found (Pinton et al. 2011). These distinctive catfishes are well represented in the Palaeogene 


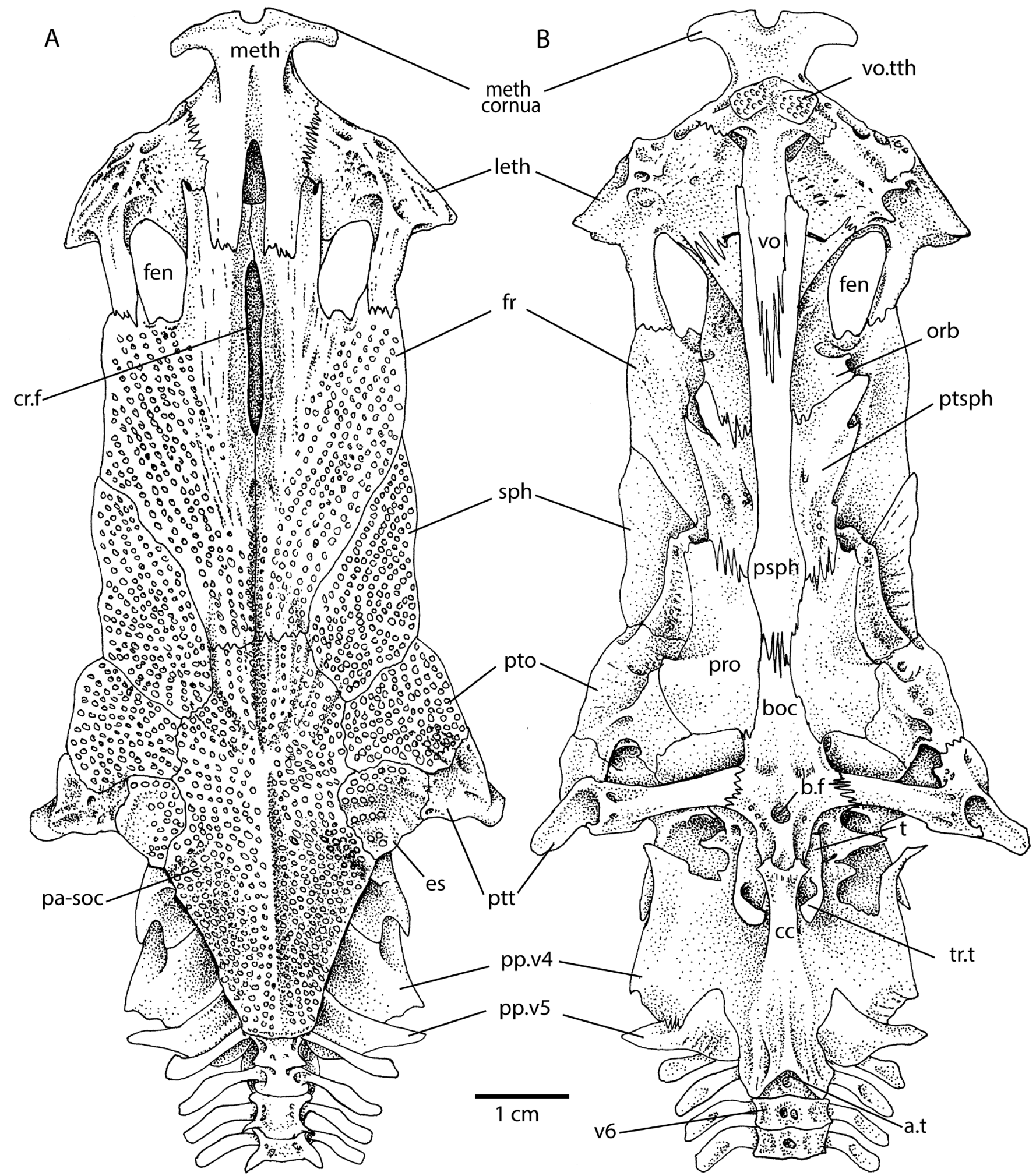

Figure 1. Skull of Ariopsis felis, ROM R1843, in A, dorsal and B, ventral views.

deposits of Africa. However, the great diversity of modern species and lack of extensive comparative collections results in most fossils not being assigned to species (Greenwood and Howes 1975; Stewart 2001). An exception to both of these statements was the study of Pinton et al. (2011), in which a partial articulated cranium from the Miocene of Chad was described as a new species in the genus Mochokus ( $\nmid$ M. gigas). We examined several species of Synodontis (Appendix 1) and figure Synodontis cf. S. budgetti Boulenger, 1911 as a representative for this family (Figs. 11, 12). 


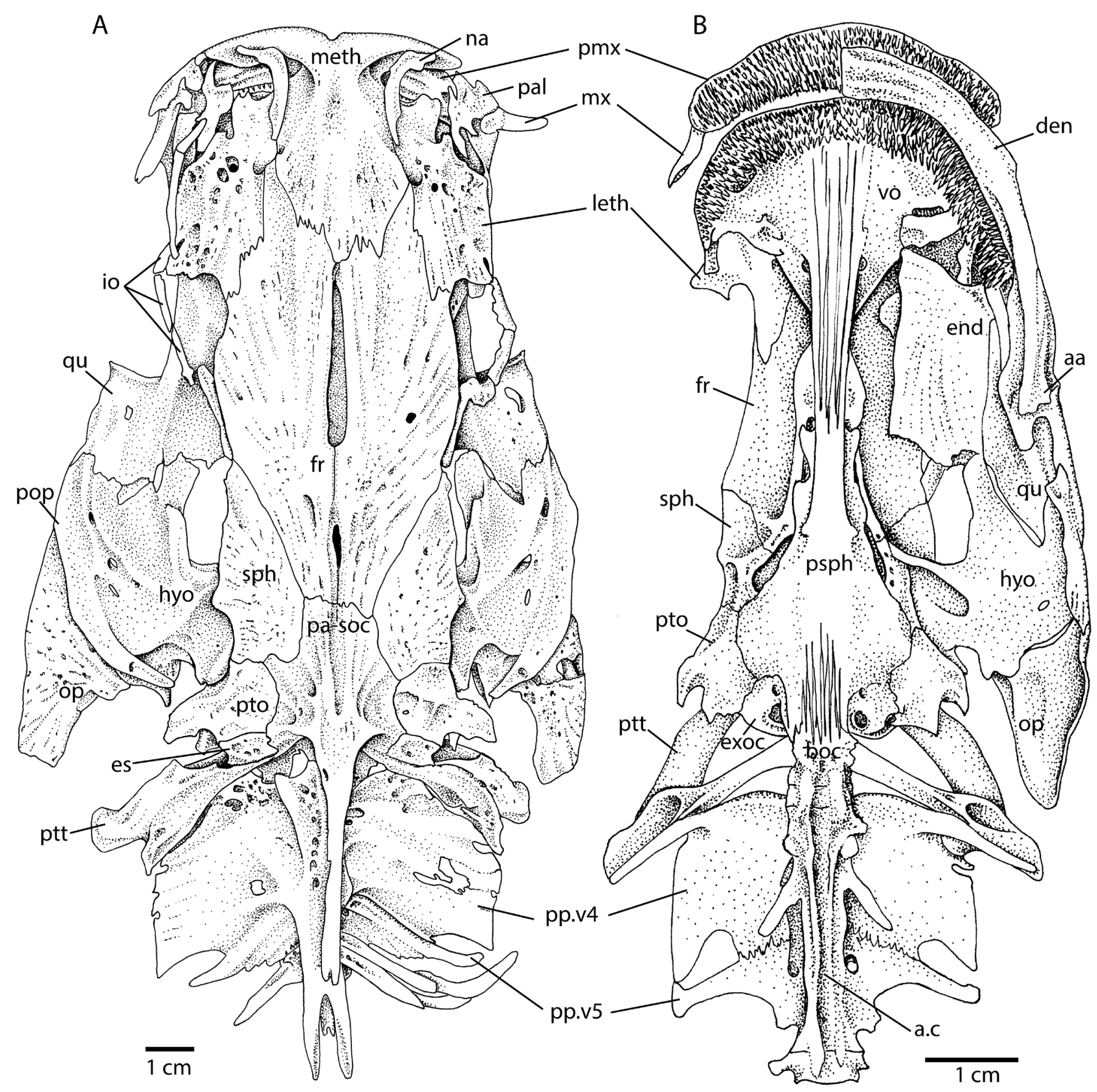

Figure 2. Skull of Bagrus docmac, CU 94690, in A, dorsal and B, ventral views.

Schilbeidae Bleeker, 1858b: The glass catfishes of the family Schilbeidae (also spelled Schilbidae, but here we follow van der Laan et al. 2014) comprise 46 species in nine genera (Froese and Pauly 2020) found in both Africa and southern Asia (Seegers 2008), with five genera containing about 33 species in Africa (Wang et al. 2016; Froese and Pauly 2020). They may or may not have a spine in the dorsal fin, and they normally have four pairs of barbels (Seegers 2008). The only possible fossil record for Schilbeidae is based on a single caudal vertebra from late Miocene deposits that is similar to vertebrae of Schilbe Oken, 1817 but was only tentatively placed in that genus (Stewart 2001, 2003). We use Schilbe intermedius Rüppel, 1832 as a representative for this family (Fig. 13) with additional information on other species given by de Vos (1995).

Plotosidae Bleeker, 1858b: The final African catfish family is Plotosidae. Plotosids are found in marine waters, and only very occasionally enter fresh waters in Africa (Seegers 2008). Only three species in a single genus (Plotosus Lacepède, 1803) are found in African waters (excluding Madagascar), on the eastern shore of the continent, ranging 


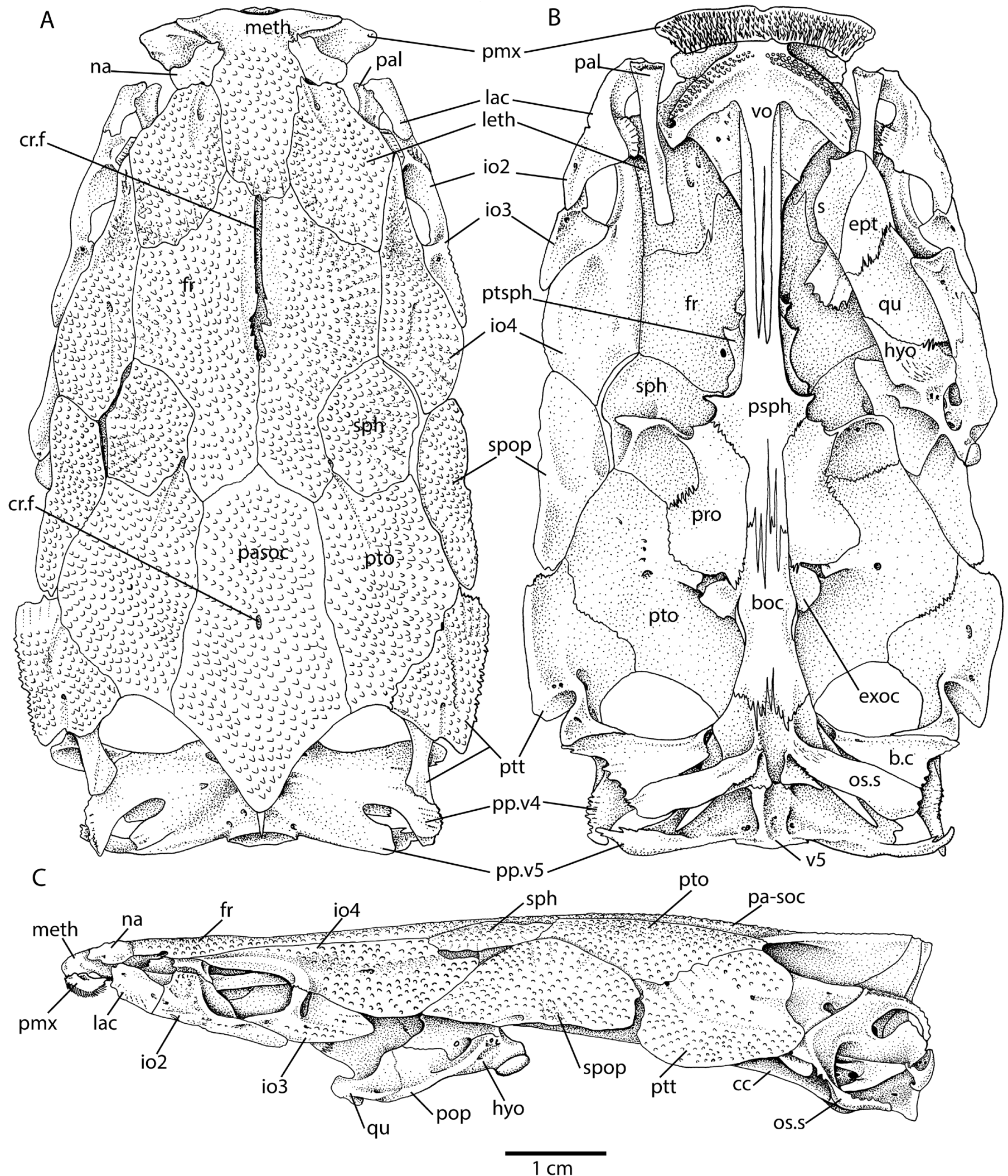

Figure 3. Skull of Clarias gariepinus, UAMZ uncataloged, in A, dorsal; B, ventral; and C, left lateral views. 


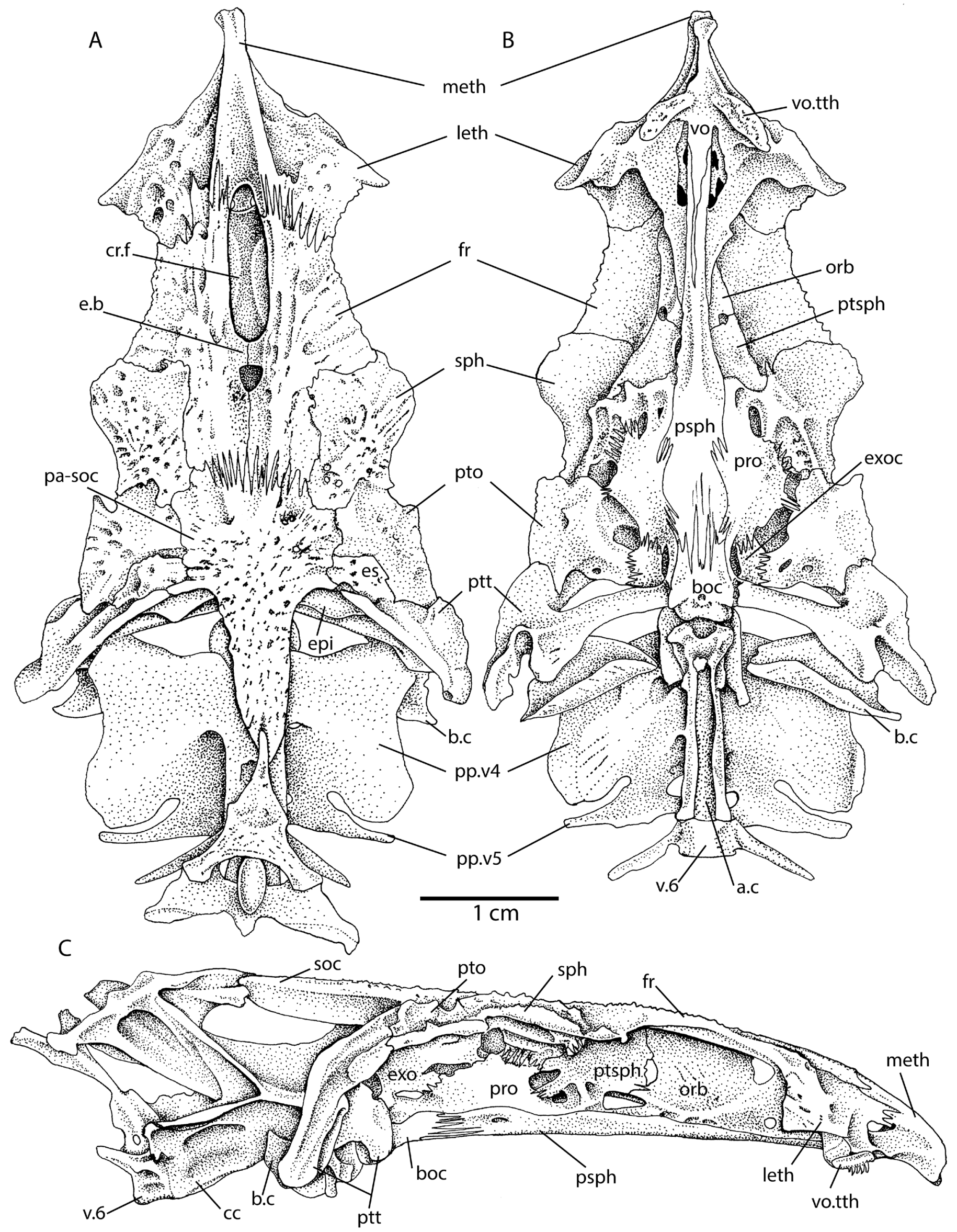

Figure 4. Skull of Chrysichthys auratus, UMMZ 21275-S, in A, dorsal; B, ventral; and C, left lateral views 


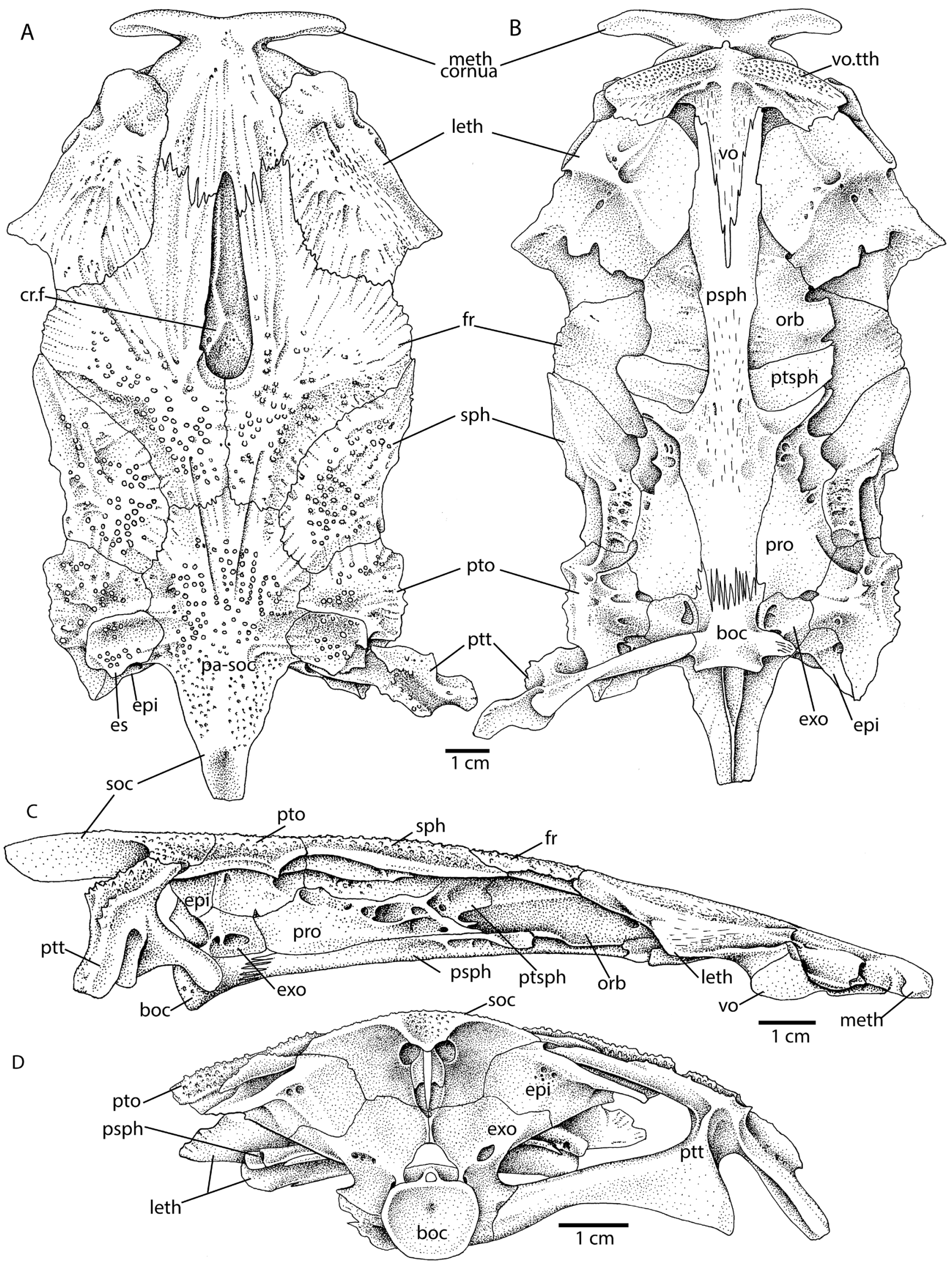

Figure 5. Skull of Clarotes laticeps, UAMZ uncataloged \#1, in A, dorsal; B, ventral; C, right lateral; and D posterior views. 


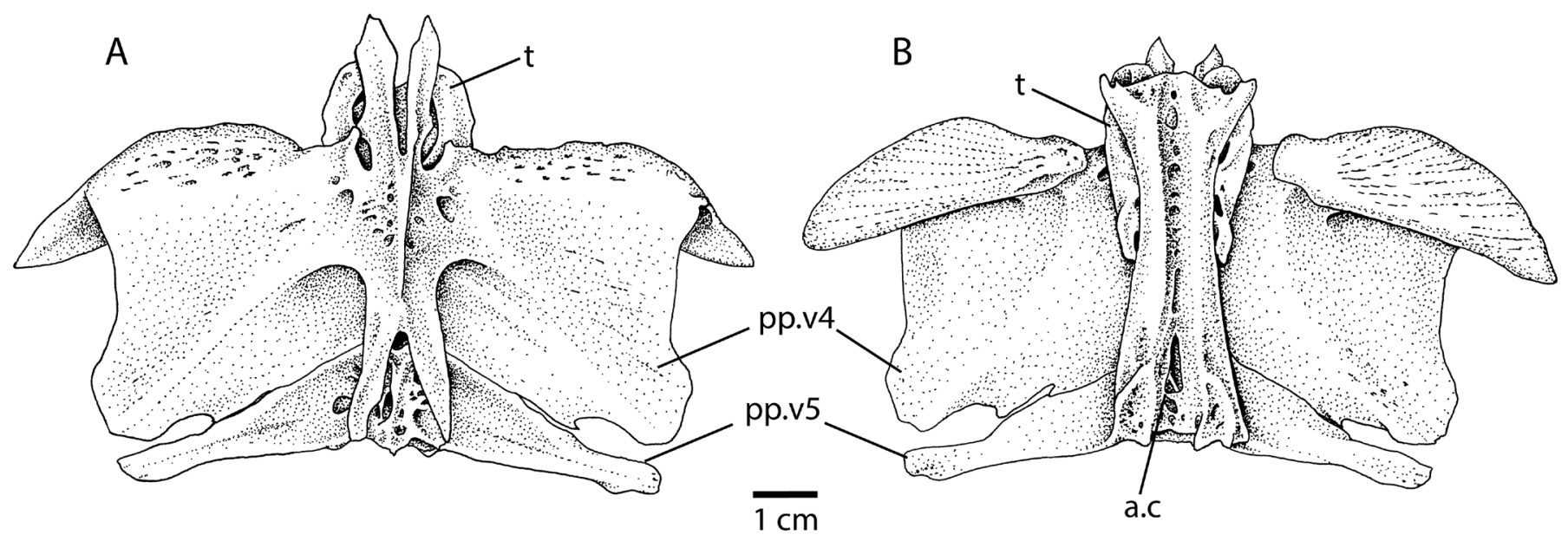

Figure 6. Weberian apparatus of Clarotes laticeps UAMZ uncatalogued \#2 in A, dorsal, and B, ventral views.

from South Africa to the Red Sea (Seegers 2008). No African fossil remains have been attributed to this family. We use Plotosus lineatus (Thunberg, 1787) as a representative for this family (Figs. 14, 15).

\section{OSTEOLOGICAL FEATURES OF AFRICAN CATFISHES}

Based on a survey of papers reporting fossils from African deposits (Argyriou et al. 2014; Greenwood 1972; Greenwood and Howes 1975; Otero et al. 2009a, 2010; Stewart 2001; Stewart and Murray 2020, Stewart et al. 2019; El-Sayed et al. 2020), the most common catfish elements found in fossiliferous deposits are pectoral fin spines, dorsal fin spines and vertebral centra. Partial, and occasionally complete, neurocrania are preserved only in some localities. Other elements commonly reported in those papers are isolated dermal bones of the skull and pectoral girdle, often identified to family or genus based on ornamentation of the bone surface, elements of the lower jaw (anguloarticular and dentary), basioccipitals and Weberian apparatuses. Variation in the pectoral and dorsal spines of African catfish families were documented by Gayet and Van Neer (1990), and, although there is greater variation than that presented in their paper (e.g., Argyriou et al. 2014), it still stands as an excellent resource for identifying those elements. We therefore do not discuss fin spines here. Jaw bones, elements of the pectoral girdle, and vertebrae are also excluded here, but should be examined in future studies. Here we concentrate on skull elements that are commonly found in fossiliferous deposits as individual bones, as well as features of articulated crania that may allow more complete fossil remains to be identified to family.

Several features that are thought to be diagnostic for some families of Africa catfishes have been presented in the literature (e.g., mochokids having a median notch in the posterior margin of the supraoccipital, Pinton et al. 2011). Others are routinely used by palaeontologists working on African catfishes, but have not been explicitly documented (e.g., ornamentation of dermal skull bones, Greenwood and Howes 1975; Otero et al. 2009a). In addition, potentially diagnostic features have come to light during the course of this study. We here assess previously reported features and identify new features that appear to be diagnostic, either by themselves or in combination with other features, that will allow at least some fossil catfish remains to be identified as belonging to extant families. The features are described below with the distribution of the features among African catfish families summarized in Table 1. [Table 1 is placed at the end of the paper, for ease of use.] We expect this table to be revised and refined with future research as new features are discovered or the ones presented here are found to be more widely distributed than currently understood.

\section{Skull roof}

Ornamentation of dermal bones: In catfishes, the dermal bones bear ornamentation in the form of bumps, ridges and grooves that may form a regular or irregular pattern. This ornamentation is distinctive for different African families and has been used to assign even fragmentary fossil cranial elements to family. The ornamentation may be prominent on all dermal bones (e.g., Ariopsis, Clarias, Synodontis, Figs. 1, 3, 10), or be more limited in distribution (e.g., Clarotes, Schilbe, Figs. 5, 12). It may be in the form of regular small bumps (e.g., Clarotes, Ariopsis) or in ridges (described as 'fibrous' by Otero et al. 2009b:68, and stated to occur only in the genus Bagrus). Malapterurus is essentially unornamented, having smooth dermal bones (Fig. 9) and Plotosus has a few pits and striations (Fig. 14). Marceniuk et al. (2012:548) noted that two ariid genera, Bagre and Galeichthys, the latter found in African waters, have a unique ornamentation of grooves and slits. 


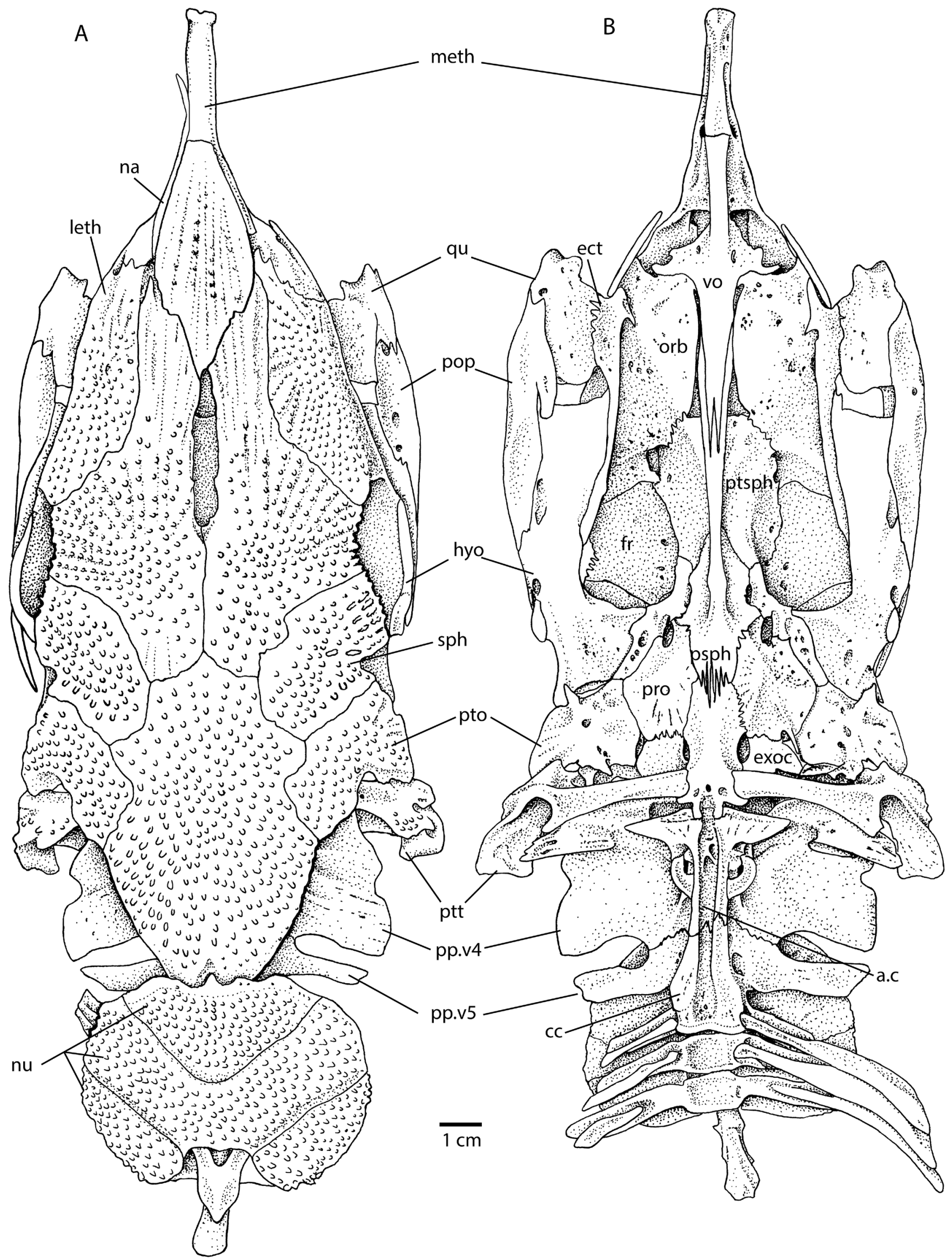

Figure 7. Skull of Auchenoglanis occidentalis, CU 90623, in A, dorsal, and B, ventral views.. 


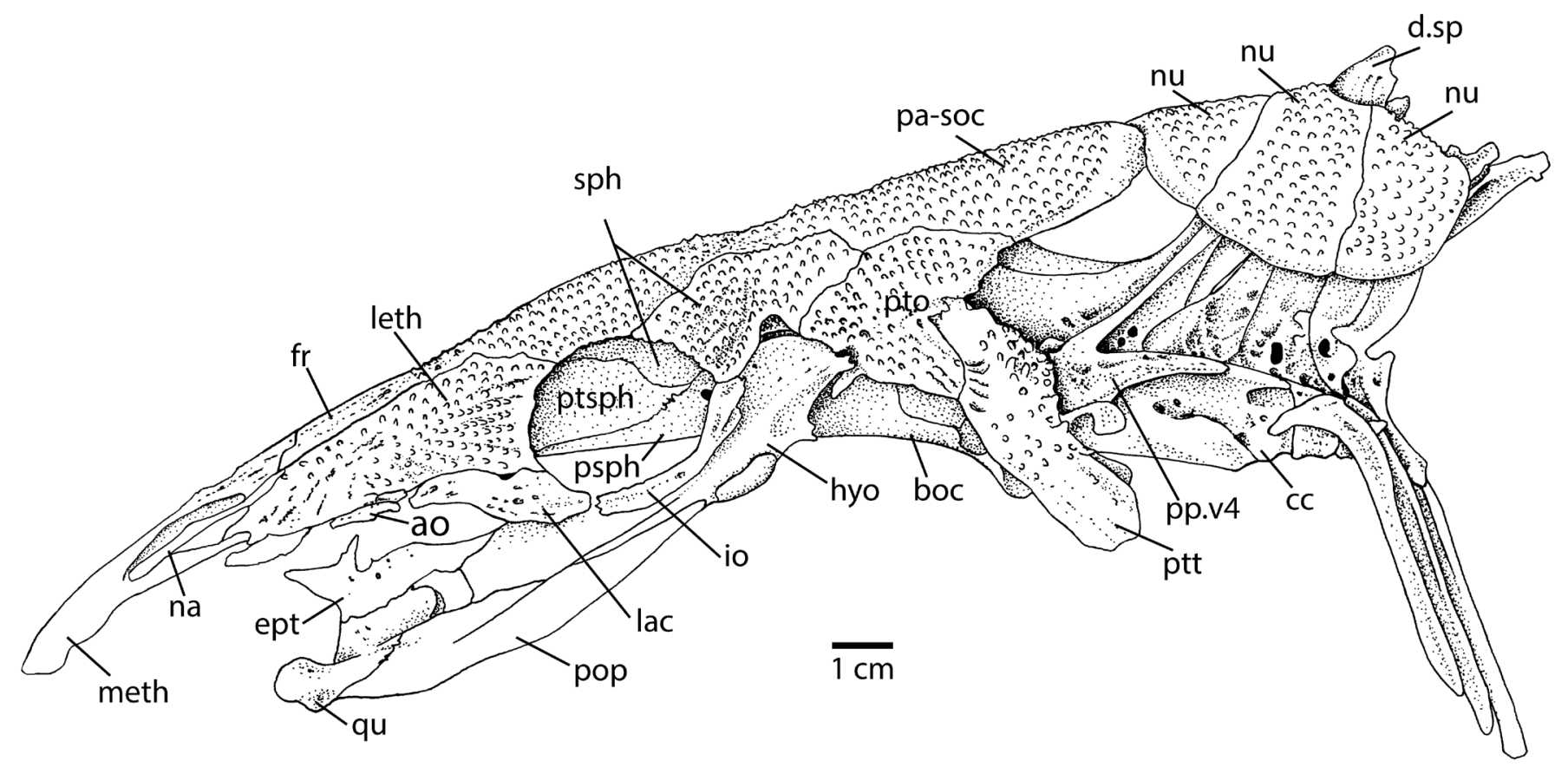

Figure 8. Skull of Auchenoglanis occidentalis, CU 90623, in left lateral view.

Cranial fontanelle(s): A large fontanelle separating the left and right frontal bones is present in numerous catfishes, but not all. The fontanelle may reach anteriorly to penetrate the posterior portion of the mesethmoid (e.g., Malapterurus, Fig. 9), or it may be limited from reaching the mesethmoid anteriorly by the left and right frontal meeting one another in the midline (e.g., Schilbe, Fig. 13). In some taxa, the fontanelle may have a bridge (epiphyseal bar) between left and right frontals that divides it into anterior and posterior portions (e.g., Chrysichthys, Fig. 4), which is lacking in other taxa, and in Clarias (Fig. 3) the anterior and posterior fontanelles are completely separate and located in different bones, with the anterior fontanelle between the two frontals and the much-reduced posterior fontanelle contained within the parieto-supraoccipital. The posterior extent of the (posterior) fontanelle varies among taxa, and may extend posteriorly to invade the anterior end of the supraoccipital crest (e.g., as in Austroglanididae, according to Mo 1991). In some taxa, the fontanelle is positioned in a median groove which extends farther than the fontanelle (e.g., Ariopsis, Fig. 1, and some other ariids, see figures in Marceniuk and Menezes 2007), whereas other taxa do not have a fontanelle groove in the midline of the skull roof (e.g., Clarias, Schilbe; Figs. 3, 13).

Presence or absence of the fontanelle could conceivably be affected by ontogeny. We do not have access to an ontological series of specimens for all species, so this is not something we can determine. However, it may be important to consider this when using the fontenalle as a feature to identify catfishes.
Mesethmoid: The mesethmoid is a distinctive element that is easily recognized in fossil deposits, even if it is represented only by a small fragment of the bone. In many catfish, the mesethmoid bears anterolateral cornua (horns) of varying prominence (compare the strong cornua of Clarotes laticeps, Fig. 5, to those of Chrysichthys auratus, Fig. 4). The left and right cornua may be separate by a notch of variable shape and size in the anterior midline (compare the deep, narrow notch of Ariopsis felis, Fig. 1, to the shallow, broad notch of Schilbe intermedius, Fig. 13). Marceniuk et al. (2012) indicated the size and shape of the notch should be useful for identification of fossil ariids.

Lateral ethmoid: The shape of the dorsal exposure of the lateral ethmoid differs among catfish. The lateral ethmoid is broadly triangular in dorsal view in some African catfishes (e.g., Bagrus docmac, Fig. 2), but in others it is truncated and square (e.g., Clarias gariepinus, Fig. 3).

Frontal: The dorsal surface of the frontal in some catfishes has a roughly rectangular shape in which the mid-portion has essentially the same width as the anterior and posterior portions (e.g., Plotosus lineatus, Fig. 14) or is at least not greatly expanded over the orbits (e.g., Ariopsis felis, Fig. 1). In other taxa, the frontal is widest in the middle, where it expands laterally above the orbit; it then narrows, in some cases to form a distinct posterolateral notch, to accommodate the sphenotic (e.g., Chrysichthys auratus, Fig. 4).

Fenestra between lateral ethmoid and frontal: In the family Ariidae, the lateral ethmoid and frontal bones connect medially and laterally delimiting a fenestra (Fig. 1 , and figures in Marceniuk and Menezes 2007). This 


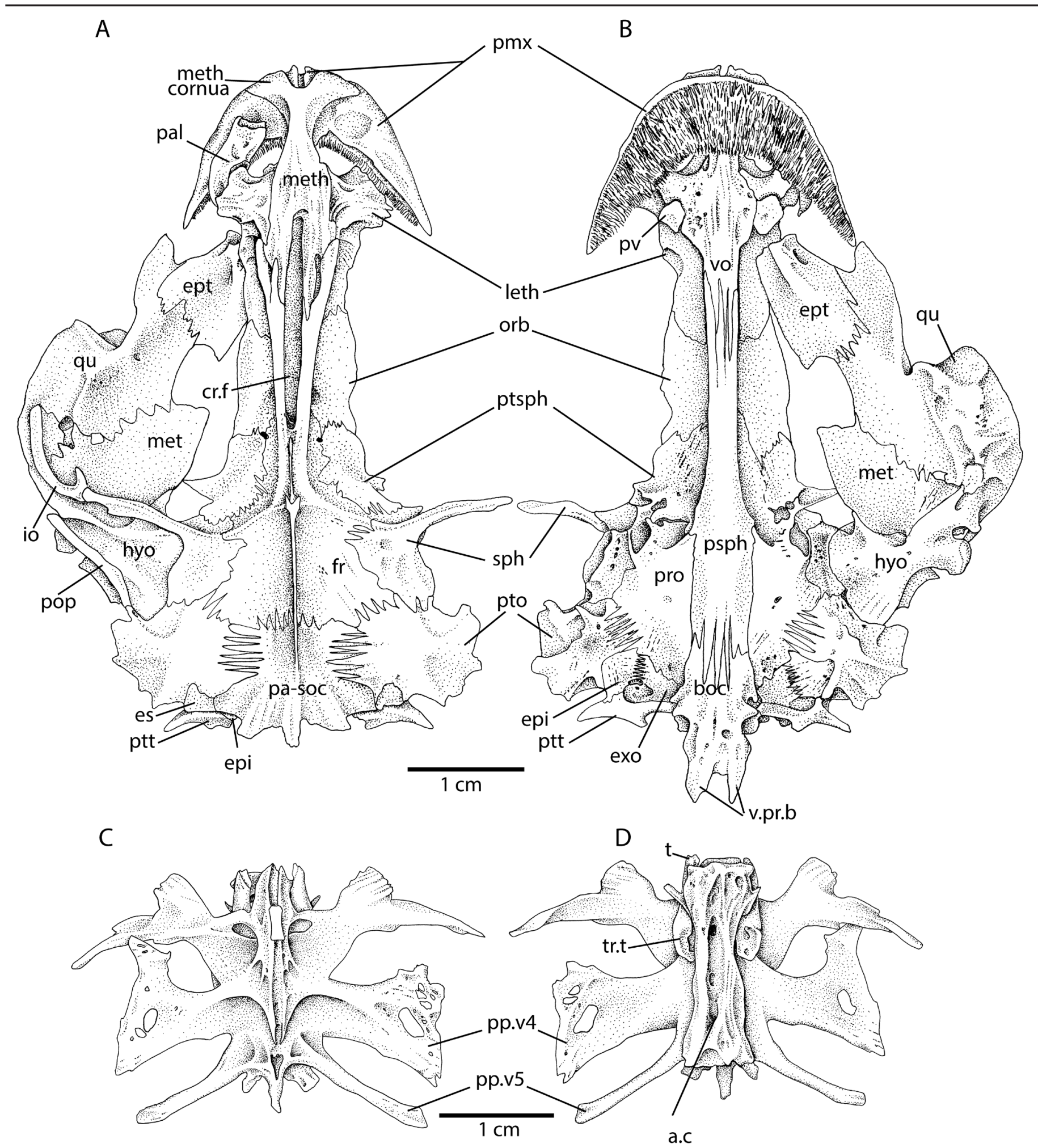

Figure 9. Malapterurus electricus, UAMZ uncataloged, skull in A, dorsal and B, ventral views; and Weberian apparatus in C, dorsal and $\mathrm{D}$, ventral views.

fenestra is absent in the other African catfishes and from all other Siluriformes.

Sphenotic: Diogo (2005) noted that the anterodorsal portion of the sphenotic is distinctly bifurcated in Austroglanididae. In most of the specimens examined in this study, the sphenotic forms part of the skull roof and is rounded posteromedially, with a straight lateral edge. The sphenotic of Chrysichthys, Malapterurus and Plotosus clearly differ. In Chrysichthys it is more square in shape and has a posterolateral notch (Fig. 4), in Malapterurus, it is triangular with a long, thin anterolateral process that meets the infraorbital series (Fig. 9), and in Plotosus, it has 


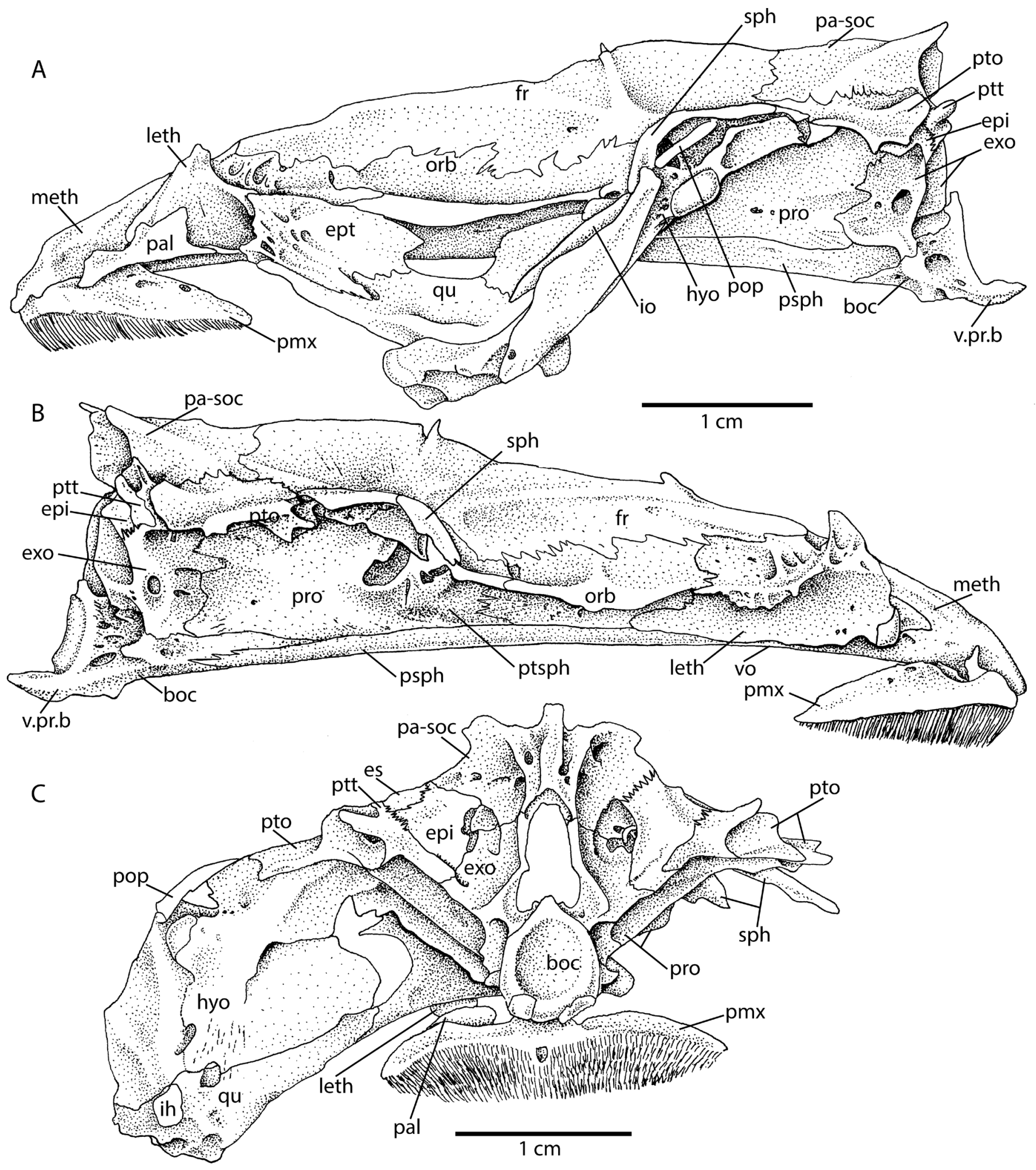

Figure 10. Skull of Malapterurus electricus, UAMZ uncataloged, in A, left lateral, B, right lateral, and C, posterior views.

an anterolateral flange with a flattened posterolateral edge (Fig. 14).

Number of bones sutured with parieto-supraoccipital: Otero et al. (2009b) stated that ariid catfishes could be distinguished by the number of bones that meet the parieto-supraoccipital on the skull roof, with five pairs being found in Ariidae and only four or three pairs in other African catfishes. The five pairs of bones were identified by Otero et al. (2009b:fig. 3d) as the epiotics (= epioccipitals), extrascapulars, pterotics, sphenotics and 


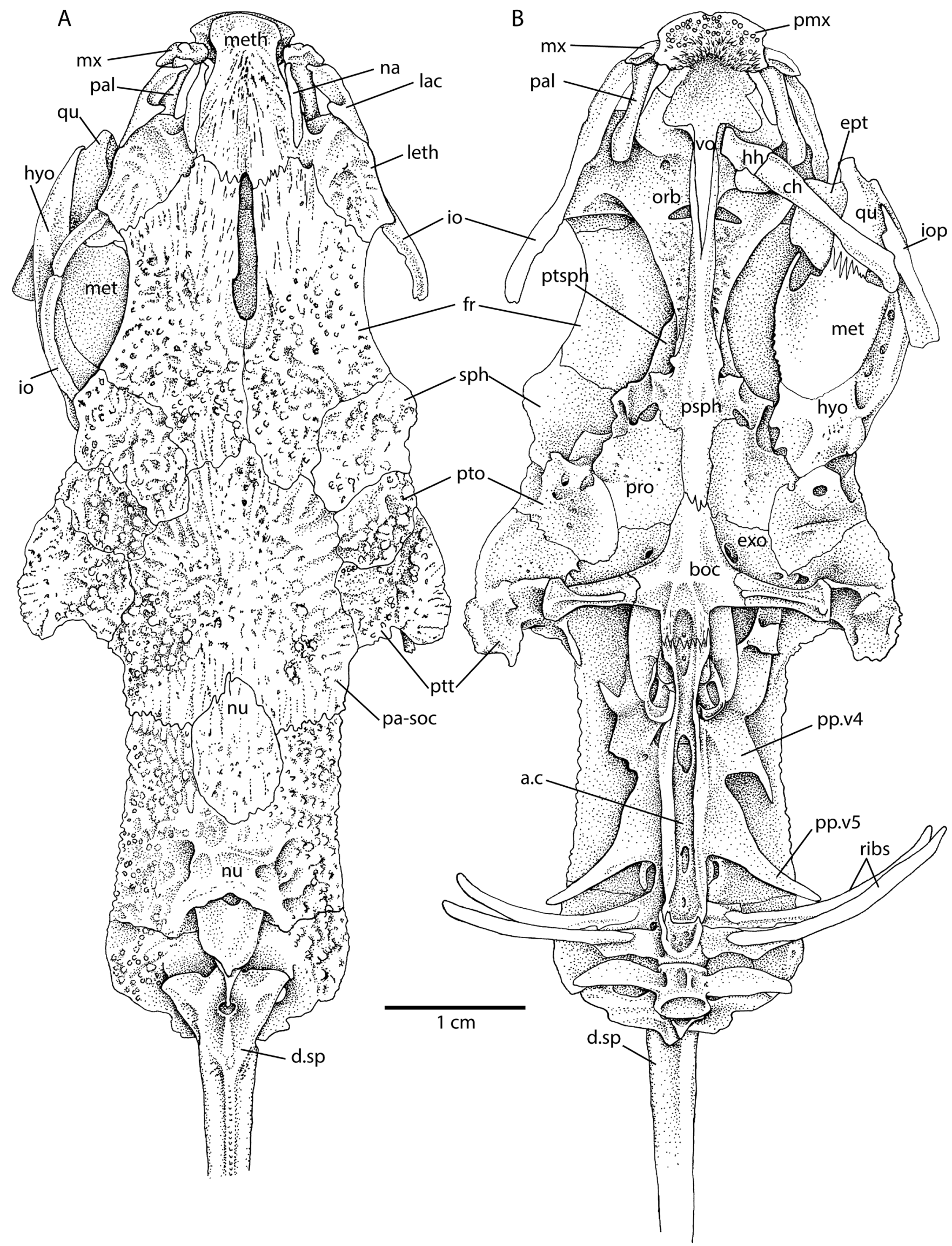

Figure 11. Skull of Synodontis cf. S. budgetti, UAMZ uncataloged, in A, dorsal, and B, ventral views. 
A

Murray \& Holmes - Cranial osteology of African catfishes

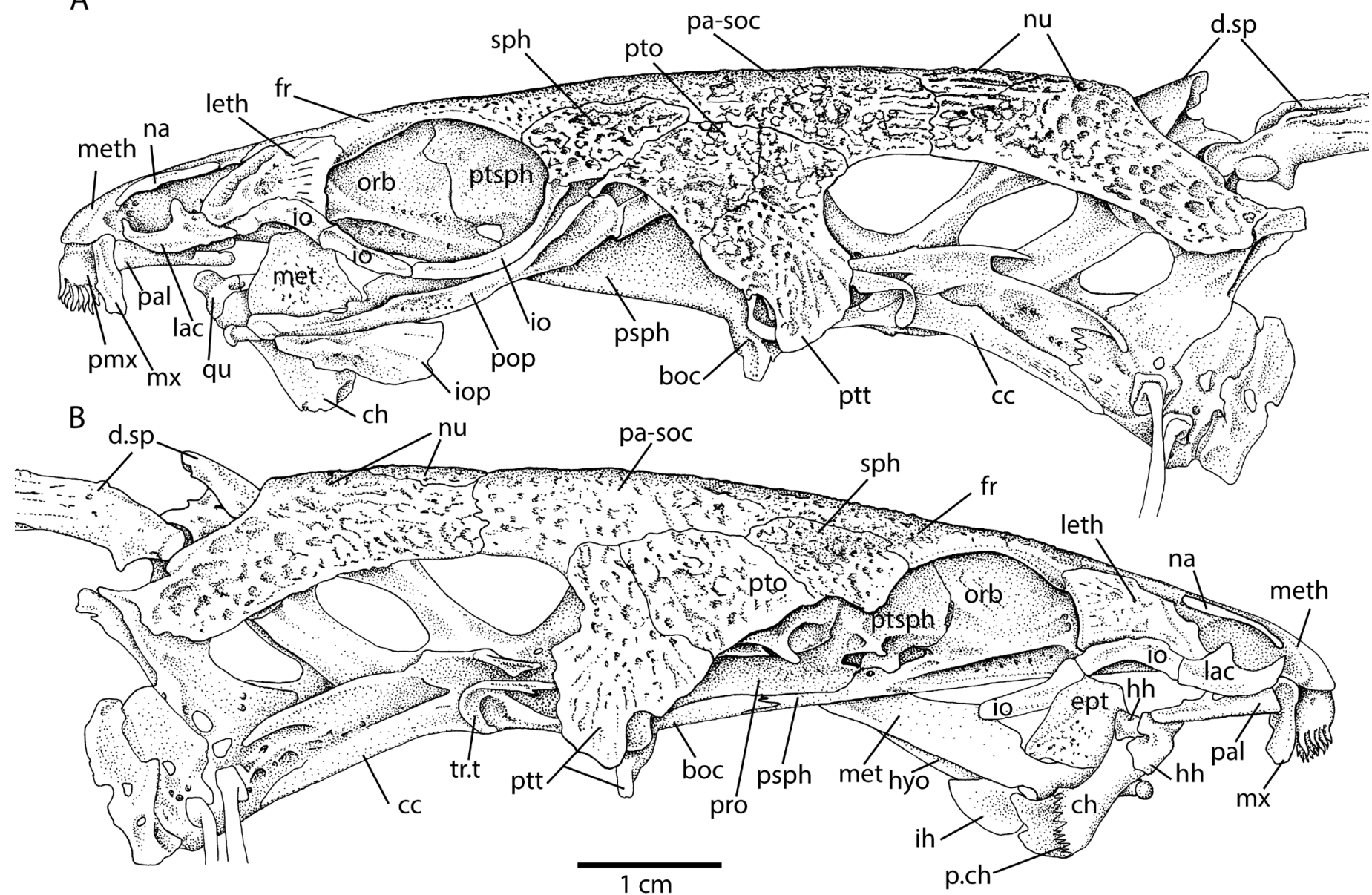

Figure 12. Skull of Synodontis cf. S. budgetti, UAMZ uncataloged, in A, right lateral, and B, left lateral views.

frontals. Marceniuk et al. (2012) provided two separate characters that influence the number of bones contacting the parieto-supraoccipital; these are: 1) the presence/ absence of the extrascapular, and 2) whether or not the epioccipital is exposed on the dorsal skull roof. Within Ariidae, there is variation among species in the number of pairs of bones meeting the parieto-supraoccipital, with some taxa having five pairs (see Marceniuk and Menezes 2007:figs. 1, 12, 81), and others with only four pairs (see Marceniuk and Menezes 2007:figs. 32, 37, 50, 59, 87, 90). We have included the number, as well as the identities, of bones contacting the parieto-supraoccipital in Table 1. The presence or absence of the extrascapular and whether or not the epioccipital is exposed on the dorsal skull roof are also listed as separate features, both below and in Table 1 .

\section{Shape of anterior edge of parieto-supraoccipital:}

If the cranial fontanelle extends posteriorly to invade the parieto-supraoccipital, the posterior rim of the fontanelle is expressed as a deep midline concavity or notch on the anterior margin of the parieto-supraoccipital. The absence of this concavity was used by Longbottom (2010), following Mo (1991), to characterize Claroteidae. We confirm the absence of this concavity in all of the claroteids (Clarotes,
Chrysichthys, Auchenoglanis) available to us. However, this is true of all other other catfishes examined in this study. In Ariopsis felis (Fig. 1), there is a midline depression that represents the continuation of the median groove that extends from the posterior rim of the fontanelle, but the fontanelle itself terminates within the frontal and does not invade the parieto-supraoccipital. Diogo (2003, 2005; Diogo et al. 2000) considered the concavity to be present in Amphiliidae, in which case this feature could be useful to identify amphiliid material, which thus far has not been identified in the fossil record. Although none of our examined taxa had the anterior notch, the anterior border of the parieto-supraoccipital does vary in general shape among the examined taxa. For example, in Clarotes (Fig. 5) and Plotosus (Fig. 14), the anterior edge is roughly straight (ignoring the interdigitating sutures with the frontals), whereas in Clarias (Fig. 3) there is a small, pointed, anterior projection in the midline of the parieto-supraoccipital.

Posterior extent of parieto-supraoccipital: Diogo (2005) considered the Malapteruridae, Mochokidae, and Auchenipteridae to be characterized by a posteriorly truncated parieto-supraoccipital bearing only a very small supraoccipital crest. The parieto-supraoccipital extends 


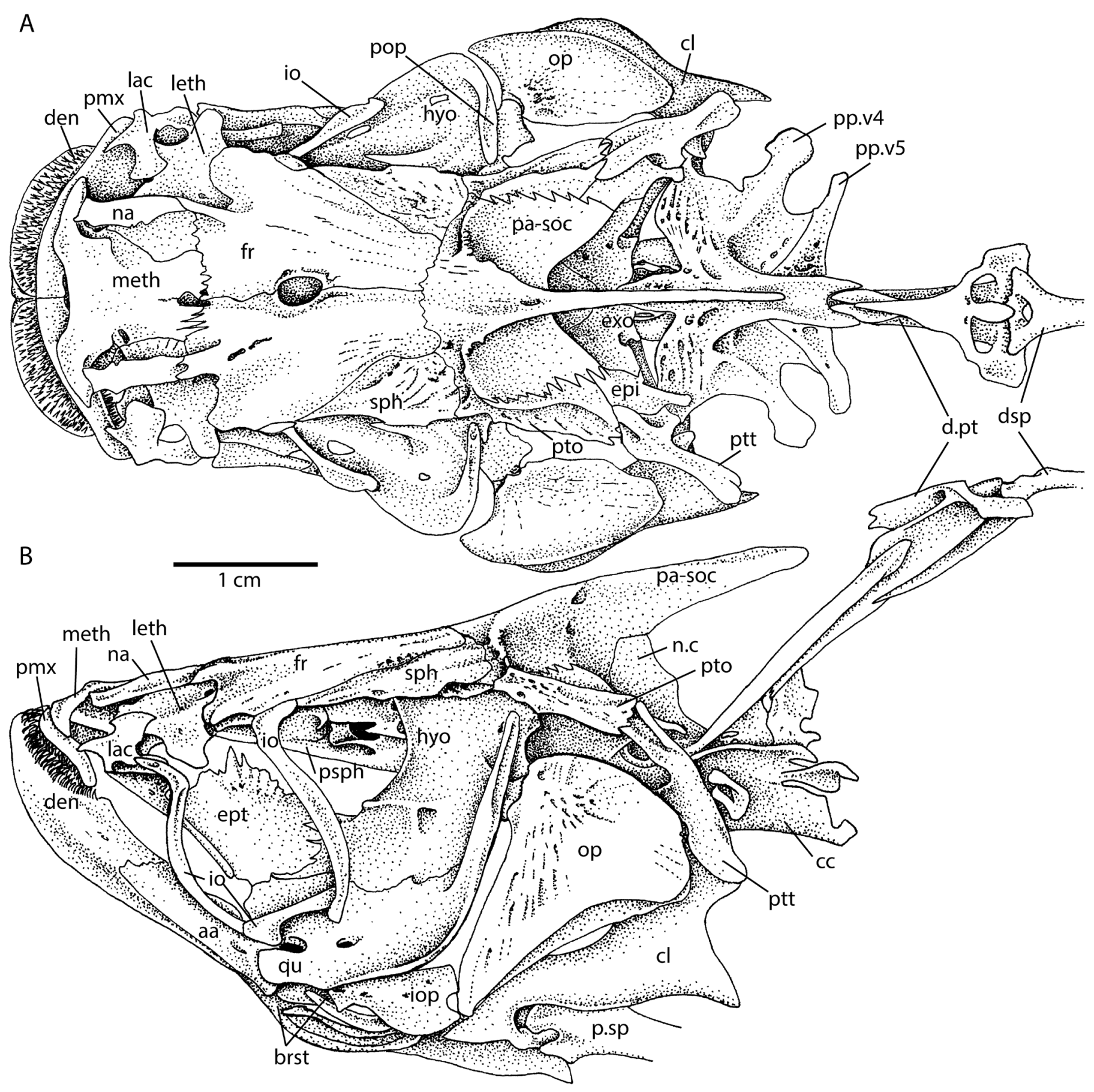

Figure 13. Skull of Schilbe intermedius, CU 94688, in A, dorsal, and B, left lateral views.

posteriorly beyond the braincase as a long crest in Bagridae and Schilbeidae (Figs. 2 and 13). In contrast, in Synodontis this bone lacks the crest but instead has a concavity in the posterior border to accept the nuchal plate (Fig. 11). We confirm the presence of a posteriorly truncated parieto-supraoccipital lacking a concavity in Malapterurus, although a small crest is present (Fig. 8). The supraoccipital crest is relatively short and broad with a flattened posterior end in Ariopsis and Clarotes (Figs. 1 and 5). In Chrysichthys (Fig. 4), it is narrower but with the same flattened poster- ior end where it meets the nuchal plate. Clarias (Fig. 3) and Auchenoglanis (Fig. 7) also have short broad crests, but these are much broader than those of Clarotes (Fig. 5) and Chrysichthys (Fig. 4).

Dorsal exposure of epioccipital: This feature is noted as a simple presence or absence of a contribution by the epioccipital to the dorsal skull roof. As noted above, the contribution of the epioccipital to the skull roof increases the number of bones in contact with the parieto-supraoccipital. In most African families, the epioccipital is con- 


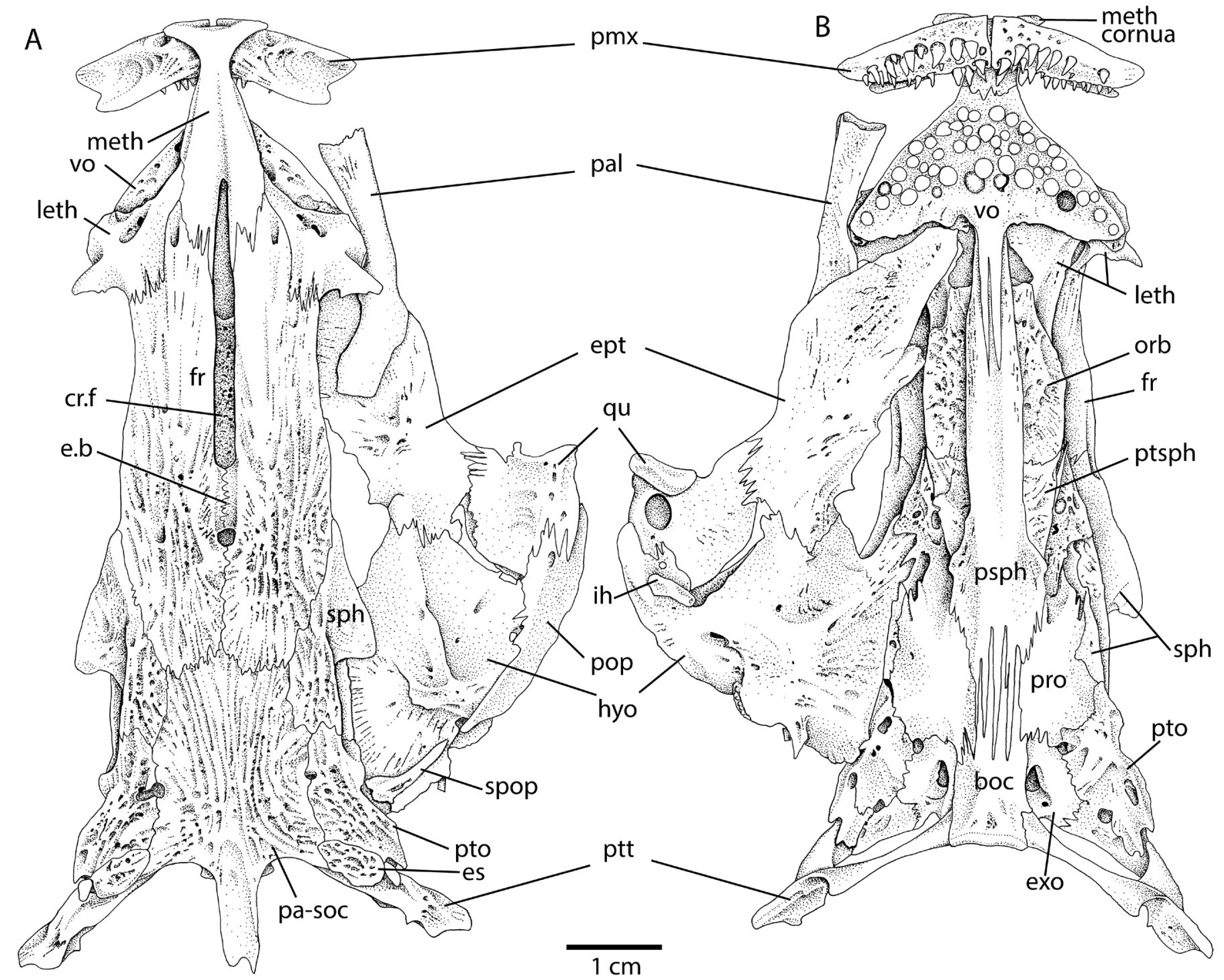

Figure 14. Skull of Plotosus lineatus, UAMZ uncataloged, in A, dorsal, and B, ventral views.

fined to the occipital aspect of the skull and is not exposed dorsally. In some ariids, the epioccipital contributes to the skull roof (Marceniuk and Menezes 2007), and in schilbeids, it is visible in dorsal view, but may not form part of the dorsal surface of the skull (Fig. 13; de Vos 1995).

Extrascapular: The extrascapular has been described as 'relatively large', 'very well developed', 'moderately large', 'very reduced' in size, or absent in different taxa of ariids (Marceniuk and Menezes 2007). Despite this variation within the family Ariidae, the presence or absence may be useful to distinguish African taxa. For example, an extrascapular is present in Bagrus (Fig. 2) and some claroteids (Chrysichthys, Clarotes, Figs. 4, 5), but absent in other claroteids (Auchenoglanis, Fig. 7) and absent in Schilbe (Fig. 13) and Clarias (Fig. 3).

Posttemporal posterior process: Although the posttemporal is technically part of the pectoral girdle, it may become integrated into the dorsal skull roof in catfishes, and so we include it here. There is a process oriented posteriorly at the midpoint of the posttemporal in Bagrus bajad; the corresponding projection is not as well developed in B. docmac (Fig. 2). This process is not seen in the other catfishes examined.

Posttemporal notch for the pterotic: Longbottom (2010) noted that in $\uparrow$ Nigerium tamaguelense there is a notch in the posttemporal that accommodates a posterior projection from the pterotic. Her figure (2010:text-fig. 9) shows the notch to be located about in the middle of the anterior surface of the posttemporal. There is no comparable notch in any of our other recent or fossil material examined; therefore, this seems to be an autapomorphy of $\uparrow N$. tamaguelense, and we do not include it in Table 1. 
A

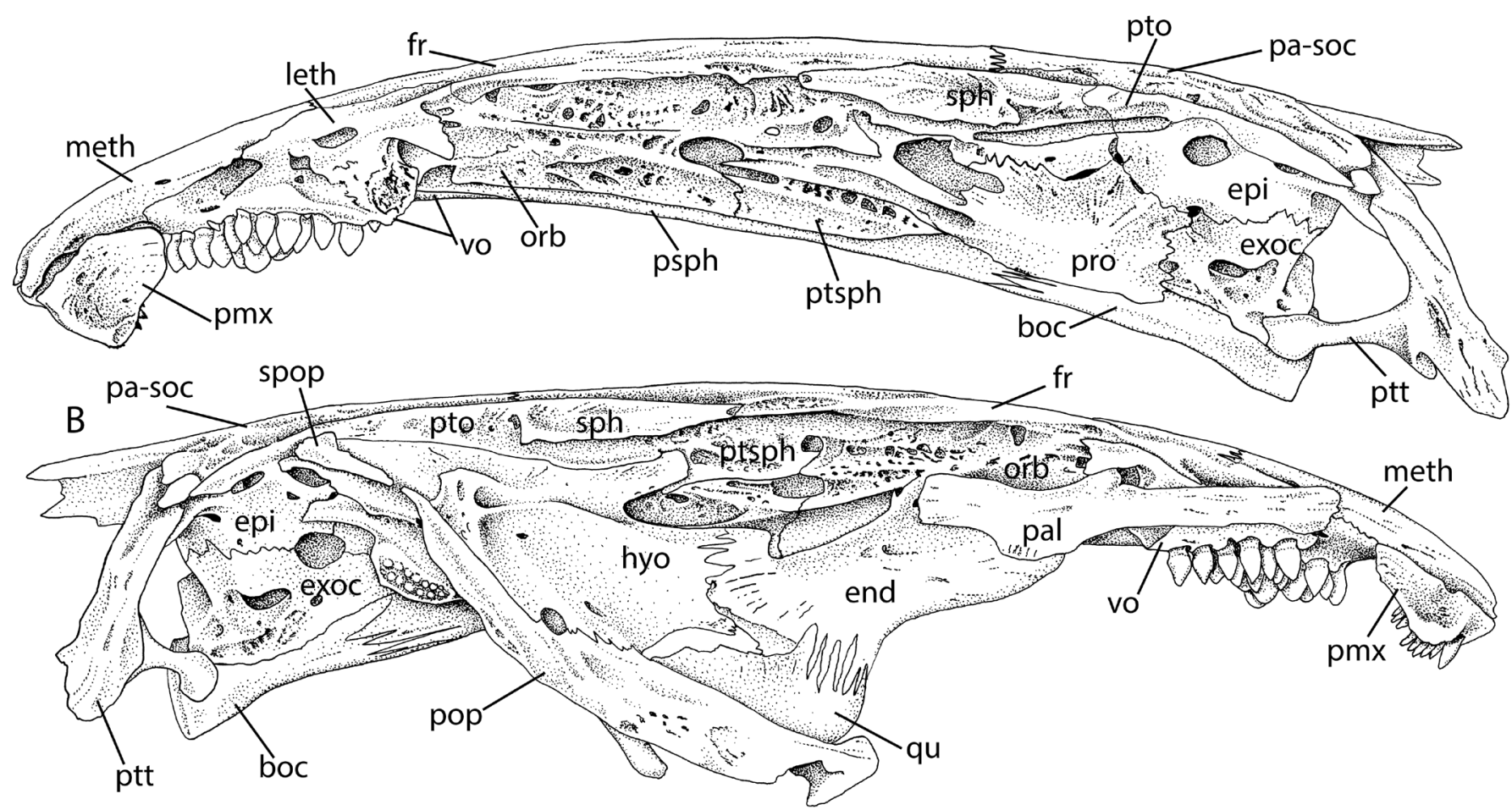

C

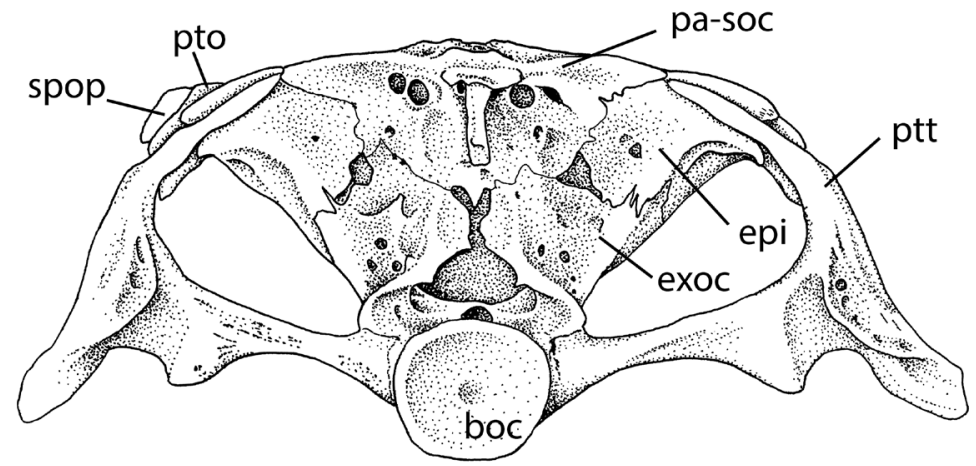

$1 \mathrm{~cm}$

Figure 15. Skull of Plotosus lineatus, UAMZ uncataloged, in A, left lateral; B, right lateral; and C, posterior views

\section{Ventral skull}

Vomer shape: Mo (1991) noted that the vomer of catfishes generally has a large crescentic head that in Bagridae has lateral tips extended beyond the lateral ethmoid facets. The vomer among African catfishes varies from T-shaped (e.g., Clarotes, Fig. 5) to arrow shaped (e.g., Clarias, Fig. 3), the difference caused by the angle of the lateral tips to the main shaft. The shaft of the vomer is relatively short (compared to the width including the lateral projections) in some (e.g., Clarotes, Fig. 5) or is quite elongate, being more than twice as long as it is wide in some ariids (Fig. 1).

Vomer teeth: Teeth, either attached to separate small tooth plates or embedded directly in the bone, are present on the vomer in some catfishes but not others. According to Mo (1991), the presence of teeth on the vomer (as in Bagridae) is the primitive condition; the derived edentate condition is present in Austroglanididae and Auchenoglanidinae. In our examined material, the vomer lacks teeth in Synodontis (Fig. 11) and Malapterurus (Fig. 9), the teeth are present embedded in the vomer in Clarotes (Fig. 5), Plotosus (Fig. 14), and Bagrus (Fig. 2), and the teeth are present but borne on small tooth plates in Ariopsis (Fig. 1). The form of the vomerine teeth varies with numerous small cardiform teeth in Bagrus (Fig. 2), fewer, slightly larger conical teeth in Ariopsis, Chrysichthys, and Clarotes (Figs. 1, 4, 5), and enlarged, round crushing teeth in Plotosus (Fig. 14). 


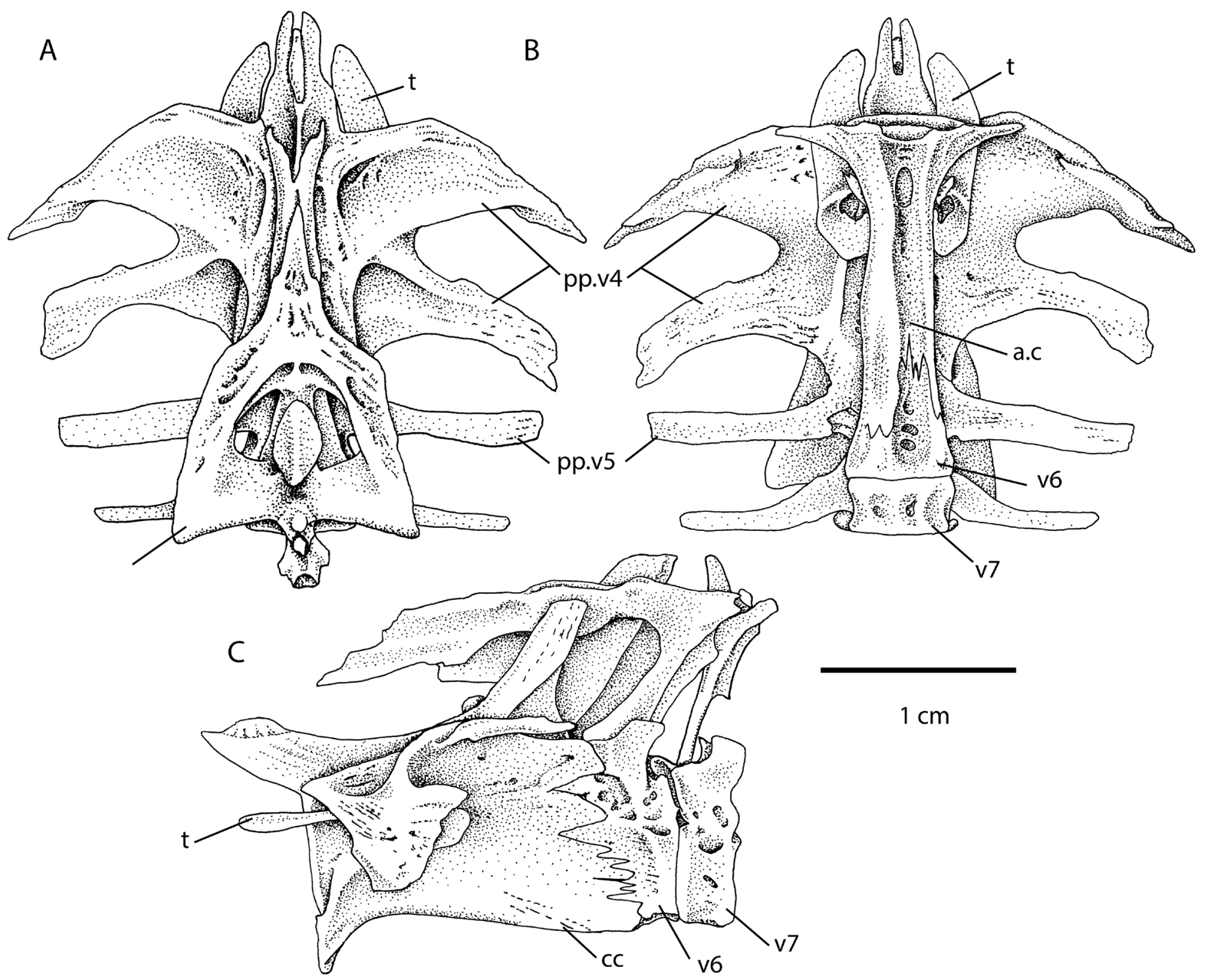

Figure 16. Weberian apparatus of Plotosus lineatus, UAMZ uncataloged, in A, dorsal; B, ventral; and C, left lateral views.

Inflation of otic capsules: In members of the Ariidae, the prootics, pterotics, exoccipitals and epioccipitals become enlarged or swollen ('inflated'), presumably correlated with the large lapillus otolith (Acero and Betancur-R 2007). This is considered a diagnostic feature for the family (Marceniuk and Menezes 2007). Among our examined material, only the ariid had significantly inflated otic capsules (not distinguishable in our illustration); however, the condition in Malapterurus also seems somewhat inflated. The other catfishes have normal (not inflated) otic capsules.

\section{Basioccipital and Weberian apparatus}

Several authors have noted that in ariid catfishes, the basioccipital is fused with, or has a very strong attachment to, the Weberian apparatus (e.g., Acero and Betancur-R 2007; Otero et al. 2009b). The lack of fusion between the basioccipital and Weberian apparatus was used by El Sayed et al. (2020) to indicate that the fossil catfish genus $\dagger$ Fayumia was not an ariid. However, Otero et al. (2009b) assigned a partial cranium, an isolated basioccipital and an isolated Weberian apparatus to Ariidae, implicitly questioning the taxonomic significance of the co-ossification of these elements. Neverthless, two other features mentioned by these authors might be diagnostic of Ariidae. These are presence of a fossa (= 'deep hollow' of Otero et al. 2009b), and presence of a prominent ventral spur (Otero et al., 2009b). This latter was described as a "well-developed ventral process of basioccipital, forming a cone-shaped projection" by Acero and Betancur-R (2007:135), and a "produced ventral process" by Kailola (1990:46). Kailola (1990) further noted that this process sutured with a subvertebral process or cone of the laminar bone enclosing the aortic canal. Acero and Betancur-R (2007) also identified a connection between the 'produced process' of the epioccipital and the sustentaculum 
of the Weberian apparatus in the subfamily Ariinae (i.e., ariids excluding Galeichthys). Kailola (1990) used the term 'pars sustentaculum' for the horizontal expansion of the complex centrum that roofs over the neural canal; however, the term 'sustentaculum' has been used in the literature (e.g., Al-Rawi 1966) to refer to every part of the Weberian apparatus that is not part of the moveable chain of ossicles, so the term includes the compound centrum, parapophyses and neural arches/complex. Therefore, the character of the connection between the basioccipital and Weberian apparatus is best broken down into several constituent parts, which are the first four characters we list in this section.

Suturing between the first vertebra and basioccipital: In most of the examined material (e.g., Auchenoglanis, Bagrus, Chrysichthys, Malapterurus), the first vertebra and basioccipital are united by connective tissue. In Ariopsis and Clarias, the two elements form sutures between the bones.

\section{Connection between the epioccipital and the}

Weberian apparatus: In Ariopsis, the dorsal expansion of the Weberian apparatus connects with the epioccipital bone. Such a contact is absent in most of the other taxa (Auchenoglanis, Bagrus, Chrysichthys, Malapterurus, Schilbe). Clarias has a unique morphology, with the Weberian apparatus well integrated into the posterior skull region.

Basioccipital ventral foramen: A 'deep hollow' on the posteroventral surface of the basioccipital was reported by Otero et al. (2009b) for ariid catfishes. This fossa is an anteroventral opening for the aorta which extends into the aortic tunnel of the Weberian apparatus. In Malapterurus and Schilbe, a shallow fossa is present, but it is not connected with an aortic tunnel and would not have accommodated the aorta. In the other catfishes (e.g., Chrysichthys, Bagrus, Clarias, Auchenoglanis) the fossa is absent. This suggests that the presence of the deep hollow is correlated with the presence of the aortic tunnel in ariids.

Basioccipital ventral process: Acero and Betancur- $R$ (2007) noted a well-developed ventral process on the basioccipital of ariids that forms a 'cone-shaped' ventral projection in lateral view; this process shares an interdigitating suture between the basioccipital and first vertebra. This feature is present in examined ariid material (Ariopsis felis). In other catfish taxa (e.g., Bagrus, Chrysichthys, Clarias, Malapterurus), this ventral projection is absent.

\section{Basioccipital paired posteroventral processes:} In Malapterurus, the basioccipital has a pair of distinct posteriorly projecting ventral extensions that underlap the anterior portion of the Weberian apparatus (Figs. 9, 10). These are absent in other taxa, except perhaps Bagrus docmac, which has small projections present, but these are not clearly enlarged as in Malapterurus.
Aortic canal or tunnel of Weberian apparatus: In all catfish, the ventral surface of the compound centrum of the Weberian apparatus bears the aortic canal to accommodate the aorta. This canal may be contained in an open groove (e.g., Longbottom 2010), or a tunnel (e.g., Acero and Betancur-R 2007) when it is bridged ventrally by a bony cover. Otero et al. (2009b) considered the ariid catfishes to be distinguished from other families by the possession of an enclosed aortic tunnel. Acero and Betancur-R (2007) noted the presence of the aortic tunnel in all ariids excluding Galeichthys (i.e., in their Ariinae). An aortic tunnel has also been described in Doradidae, Ariidae, Mochokidae and Pimelodidae by Longbottom (2010). Longbottom (2010) also reported an aortic tunnel present in 'Ageniosidae' and 'Centromochlidae' but these are not valid families (see van der Laan et al. 2014); presumably they are related to the genera Centromochlus and Ageneiosus both of which are in Auchenipteridae (Froese and Pauly 2020). The aortic canal is open ventrally in Bagrus, Clarias, Chrysichthys, all three claroteids, Malapterurus, Plotosus and Schilbe (Figs. $2,3,4,6,7,9)$. An open aortic canal is also present in all Synodontis specimens examined (e.g., Fig. 11).

Transverse lamina: The broad, horizontal blade of bone projecting laterally from the compound centrum in catfishes is formed by the parapophyses of the fourth and fifth vertebrae (Chardon 1968; Chardon et al. 2003). In our examined material, a clear suture between the fourth and fifth parapophyses is usually retained proximally, with the parapophyses separated distally by a relatively small cleft (e.g., Ariopsis, Bagrus; Figs. 1, 2), although in some cases, a deep cleft separates the parapophyses into two distinct projections (e.g., Malapterurus, Fig. 10, Synodontis, Fig. 11, Plotosus, Fig. 16) with only a small amount of contact between the parapophyses proximally. In claroteids (e.g., Clarotes, Fig. 6) the anterior portion of the parapophysis on the fourth vertebra is thickened, forming an inflated pad that connects with the anterior wall of the gas bladder (e.g., Chardon 1963:figs. 23, 24). Clarias also has an anteroventral expansion (bony capsule; Fig. 3) that supports the gas bladder.

\section{RESULTS}

\section{Familial designation of Palaeogene catfishes}

Based on the above anatomical review of the cranium and Weberian apparatus osteology of the African catfish families, the probable relationships of the previously named Palaeogene taxa can be assessed. As noted in the Introduction, there are three Palaeocene and ten Eocene species named for fossil catfish crania, placed in seven fossil and three extant genera.

The Palaeocene catfishes are all from Nigerian deposits; these are $\dagger$ Eomacrones wilsoni, $\dagger$ Nigerium wurnoense and $\uparrow N$. 
Murray \& Holmes - Cranial osteology of African catfishes

gadense. A third species of $\uparrow N i g e r i u m, ~ \uparrow N$. tamaguelense, is from Eocene deposits of Mali. These species have all been associated with Bagridae sensu lato (i.e., including claroteids) and Claroteidae (White 1934; Longbottom 2010).

The dermal ornamentation in $\dagger$ Nigerium wurnoense is similar to that of $\uparrow N$. tamaguelense in consisting of densely packed, radiating rows of small, round tubercles. The dermal ornamentation of $\uparrow N$. gadense is different, with the tubercles being more irregular in shape and joined with one another at their bases, perhaps better described as interconnected tubercles, or tuberculated ridges. Based on our examination of African catfish specimens, we agree that $\dagger$ Nigerium wurnoense White, 1934 (the type species), and $\dagger N$. tamagueltense are congeneric, but that the third species, $\dagger^{\prime} N$.' gadense, should be removed from the genus. This supports the reticence of White (1934) who felt that $\dagger N$. gadense should only provisionally be referred to $\dagger$ Nigerium. $\dagger$ Nigerium tamaguelense is the best represented of these three species. It has a dermal ornamentation of densely packed, small, round tubercles, or bumps, radiating in rows; the single cranial fontanelle penetrates the posterior end of the mesethmoid and continues as a distinct groove that extends both anteriorly in the mesethmoid and posteriorly onto the parieto-supraoccipital (Longbottom 2010:text-figs. 2, 3, 5, 6; plates 1, 2; pers. observ. AMM). These are features found in ariids including Ariopsis (Fig. 1). The mesethmoid of $\dagger N$. tamaguelense is absent or incomplete anteriorly in the specimens, so the condition of the cornua cannot be determined. The compound centrum of the Weberian apparatus has an open aortic canal, unlike the aortic tunnel of ariids. There is a notch in the posttemporal, as noted by Longbottom (2010) but this appears to be an autapomorphy of the species. $\uparrow$ Nigerium wurnoense and $\dagger ' N$. gadense are represented by fewer specimens, of which one of each were figured by Longbottom (2010: plate 3); specimens were also examined by one of us (AMM). These species also have the cranial fontanelle extending posteriorly as a groove past the frontal and onto the parieto-supraoccipital.

Whether or not any of the specimens shows inflated otic capsules, as found in ariids, is difficult to determine. Three specimens of $\uparrow N$. tamaguelense seems to show this condition (NHMUK P. 66681, 66697, 66700) but a fourth does not (NHMUK P.66691). However, this is a feature that we would expect to be crushed or otherwise obscured in a fossil, so the apparent condition in these specimens is difficult to assess. Although Longbottom (2010) indicated the presence of a bulging prootic in one specimen, she considered the cavity for the utricular otolith to be contained entirely in the prootic, unlike the condition in ariids, in which the pterotic and exoccipital also contribute to the cavity. Based on our examination of the specimens, we believe (contra
Longbottom 2010) that the pterotic and exoccipital both contribute to the cavity.

White (1934) diagnosed the genus $\dagger$ Nigerium as having a median cranial groove extending posteriorly from the cranial fontanelle to reach the centre of the parieto-supraoccipital, a strongly arched and high posterior skull, broad articulation on the pterotic and sphenoid for articulation of the hyomandibula, and vertical posterior wall of the skull. Longbottom (2010) emended the generic diagnosis with features of the pectoral girdle and length of parieto-supraoccipital process (= supraoccipital crest), but these are only preserved in $\dagger N$. tamaguelense, and so probably best considered diagnostic of that species alone. She also noted several other features which are more broadly distributed among catfish families. The features provided in White's (1934) original diagnosis seem most similar overall to Claroteidae among the African families (e.g., Clarotes, Fig. 5D). Despite the similarities of the extension of the fontanelle groove onto the parieto-supraoccipital and the dermal ornamentation being most similar to ariids, the three fossil species lack the basioccipital foramen for the aorta that is found in ariids and the Weberian apparatus was not preserved in articulation with any of the skulls, indicating it was not firmly attached as in ariids. We therefore agree with Longbottom (2010) and $\mathrm{Ng}$ (2003) that these three species are best placed in Claroteidae.

$\dagger$ Eomacrones wilsoni, also from the Palaeocene of Nigeria, is represented by numerous articulated crania (Cappetta 1972) but unfortunately these were not described in detail nor figured. The holotype of $\dagger E$. wilsoni (White 1934:textfig. 13) is a partial cranium missing the anterior mesethmoid and the posterior part of the skull. Based on White's figure and our examination of the holotype, there is a large cranial fontanelle with a narrow epiphyseal bar more or less in the middle of its length. The posterior extent of the fontanelle penetrates deeply into the parieto-supraoccipital. The dermal ornamentation is formed of anastomosing ridges and pits, that generally radiate out from the middle of the parieto-supraoccipital or run longitudinally along the skull. Although there are not many features preserved on the specimen, it clearly resembles Bagrus in the ornamentation and the extent of the cranial fontanelle. Although White (1934) and Cappetta (1972) assigned this species to Bagridae prior to Mo's (1991) revision of the family, we confirm that it should be kept in Bagridae sensu stricto. $\dagger$ Eaglesomia eaglesomei was originally placed in the genus Chrysichthys, indicating it would have been in Claroteidae, not Bagridae, following the revision of the group by Mo (1991), and this taxon was tentatively referred to Claroteidae by $\mathrm{Ng}$ (2003). It has a dermal ornamentation of small bumps scattered over the skull but concentrated in the postero-lateral portions. The broadly rounded posterior 
rim of the cranial fontanelle is formed by the frontals, and there is no groove continuing posteriorly from the fontanelle (White 1926:pl. 14, 15; pers. observ. AMM). Two strong, converging ridges cross from the posterior part of the frontals onto the parieto-supraoccipital, as in Clarotes laticeps (Fig. 5). The supraoccipital crest is missing, as is the anterior portion of the skull including the mesethmoid. A preserved Weberian apparatus associated with the holotype (White 1926:plate 14 fig. 3b) preserves the passage for the aorta in the compound centrum; it is in the form of a tunnel with broadly open ends. The ventral surfaces of the skulls provide few details; the vomers and posterior portion of the basioccipitals are not preserved, and the otic region does not appear to be inflated. There is limited information for assigning $\dagger$ Eaglesomia to a family, but its placement in Claroteidae is not contradicted by the skull morphology and it seems more similar to Clarotes than either Chrysichthys or Auchenoglanis. As noted by White (1926), the Weberian apparatus of $†$ Eaglesomia is similar to ariids in having an aortic tunnel; however, this area is covered with sediment and broken in the specimen, so the extent of the tunnel is not clear. $\dagger$ Eaglesomia also lacks the strong connection between the Weberian apparatus and the basioccipital found in ariids. Whether or not there was a basioccipital foramen for the aorta (as in ariids) cannot be determined. We here assign Eaglesomia eaglesomei to Claroteidae, based on the morphology and ornamentation of the skull.

The Tanzanian Eocene catfish, $\dagger$ Chrysichthys mahengeensis, is preserved essentially in 2-dimensions embedded in the matrix, unlike the rest of the Palaeogene catfishes. The holotype of this specimen preserves soft tissue features - the nasal barbels - that in combination with several osteological features are what Murray and Budney (2003) used to place it in the extant genus. The dermal ornamentation of $\uparrow C$. mahengeensis is formed of small pits, not bumps or ridges (Murray and Budney 2003). This species has a long, narrow, anteriorly-tapering, mesethmoid with weakly developed cornua, and a deep cleft posteriorly to form the anterior portion of the cranial fontanelle. The fontanelle is relatively short compared to the skull length, but whether or not it penetrates the parieto-supraoccipital is difficult to determine (Murray and Budney 2003). The supraoccipital crest is short, and not very broad. In all these features, this species matches Chrysichthys, therefore, we concur that it is correctly placed in this genus and in the family Claroteidae.

We recently described an Eocene species ( $†$ Clarotes eocenicus) from freshwater deposits of the Jbel Qatrani Formation of the Fayum Depression, Egypt and placed it in the Claroteidae (Murray and Holmes 2021). This species shares features (such as robust, laterally oriented anterior cornua of the mesethmoid, cranial fontanelle contained in the me- sethmoid and frontals not extending into the parieto-supraoccipital, dermal ornamentation of small bumps concentrated on the posterior part of the skull, and supraoccipital crest short and broadly triangular) with extant Clarotes laticeps, to the exclusion of other extant claroteid genera (Chrysicthys and Auchenoglanis). Therefore, we included it in the extant genus Clarotes as a new fossil species.

The rest of the named African Palaeogene taxa are six species in five genera, all from Eocene marine deposits of Egypt. The most recently named is $\dagger$ Qarmoutus hitanensis El-Sayad et al., 2017, from the Birket Qarun Formation. This fish was determined to have synapomorphies of Ariidae and was included in a phylogenetic analysis of ariid intra-relationships (El-Sayad et al. 2017). †Qarmoutus hitanensis has a dermal ornamentation of ridges and bumps that radiate on the posterior skull bones and are arranged in longitudinal rows on the frontals and anterior bones (ElSayed et al. 2017). The anterior cornua of the mesethmoid are not preserved, but the bone is not distinctly narrowed just behind the anterior head. The posterior portion of the mesethmoid delimits the anterior portion of the cranial fontanelle (El Sayed et al. 2017). The cone-shaped projection on the basioccipital that is found in ariids appears to be present in †Qarmoutus hitanensis (El-Sayad et al. 2017: fig. 4), and the Weberian apparatus is firmly united with the skull. Based on all of these features, we concur with ElSayad et al. (2017) that this fossil is an ariid.

The other five Egyptian species were named about 100 years ago. These are $†$ Socnopaea grandis, $\dagger$ Fajumia schweinfurthi, $\dagger F$. stromeri, and $\dagger$ Eopeyeria aegyptiacus, all from the Qasr-el-Sagha Formation of the Fayum Depression, and $\uparrow$ Arius frassi from Mokattam, near Cairo.

$\dagger$ Socnopaea grandis Stromer, 1904 was named for one incomplete skull, a basioccipital and two pectoral spines. A second skull was illustrated by Peyer (1928:pl. III, fig. 3). Both of these are large skulls with a dermal ornamentation of small bumps arranged in long parallel to radiating rows, that form long ridges in the illustration of Peyer (1928:pl. III, fig. 3). In Stromer's (1904:pl. I, fig. 3) illustration, there are two cranial fontanelles associated with a single groove, the full extent of which is not preserved. In Peyer's (1928:pl. III, fig. 3) illustrated skull, there is a single small fontanelle in a long cranial groove that clearly extends onto the parieto-supraoccipital. Several specimens in the Natural History Museum, London have been referred to $\dagger$ Socnopaea sp. (NHMUK P.10241- a Weberian apparatus with several more posterior centra attached, and P.10242 a series of twelve vertebrae) as well as to †Socnopaea grandis (NHMUK P.10258 a large skull missing the posterior part). Based on the two illustrated skulls and the NHM material, $\uparrow$ Socnopaea grandis has a broad, short mesethmoid with robust cornua and the cranial fontanelle groove 
Murray \& Holmes - Cranial osteology of African catfishes

penetrates the posterior end of the mesethmoid and the parieto-supraoccipital. There are two cranial fontanelles in the holotype (Stromer, 1904:fig; 3), both apparently contained in the frontals, with the more anteriorly positioned one probably at the level of the orbits. The single fontanelle of the skull illustrated by Peyer (1928:pl. III, fig. 3 ) is also between the frontals. The skulls are quite flat, not vaulted or with a high posterior portion as in mochokids or $\dagger$ Nigerium. There is little information in the descriptions by Stromer (1904) or visible on the NHM specimens with which to place $\dagger S$. grandis in a family; however, Peyer (1928) gave a much more detailed description and thought $\dagger$ Socnopaea may be close to the Ariidae, although he chose not to include it formally in that family. A re-examination of this species is planned by another researcher (S. El-

Sayed, pers. comm. Feb. 2020). For now, we can state that the dermal ornamentation and the aorta canal enclosed in a tunnel are features shared with Ariidae, and the shape of the mesethmoid and the cornua, as well as the morphology of the cranial groove and (less so) the fontanelles are most similar to Bagridae. However, the two ridges crossing from the frontals to converge on the parieto-supraoccipital and the broadly triangular supraoccipital crest (Peyer 1928:textfigs. 4a, 5a) are most similar to Clarotes (Fig. 5). Therefore, $\dagger$ Socnopaea shares features found in three different extant families: Bagridae, Claroteidae, and Ariidae. It may be that $\dagger$ Socnopaea represents a unique (extinct) family of catfishes. However, we await the results of the planned re-study of this taxon to resolve the question of its relationships.

$\dagger$ Fajumia schweinfurthi was first described by Stromer (1904) then Peyer (1928) added a second species to the genus, $\dagger F$. stromeri. Stromer (1904) described a flattened skull with a very broad, truncated supraoccipital crest preserving a posterodorsal indentation to accommodate the first nuchal plate, and deep furrows running on either side of the fontanelle groove from the frontal to converge on the parieto-supraoccipital; these features are somewhat reminiscent of Clarotes (Fig. 5), however, the illustrations of Stromer (1904:pl. I, fig. 2) and Peyer (1928:pl. I, fig. 1a) show the posterior edge of the parieto-supraoccipital to be much shorter and broader than that of Clarotes. The fontanelle groove in both species of $†$ Fajumia is confined to the anterior part of the skull, and the fontanelle itself is single, and positioned in the mesethmoid or the mesethmoid and frontals (Peyer 1928:pl. I, fig 1a; pl. IV, fig.1). The dermal ornamentation of both species is most similar to that of ariids; however, there is no evidence of a ventral coneshaped projection on the basioccipital, and the Weberian apparatus is not attached to the skull in the illustrated material, indicating it was not firmly sutured to the skull in life. The mesethmoid is relatively short and broad, with robust, but short, lateral cornua, there is no evidence of a fenestra between the lateral ethmoid and frontal and the aortic canal is an open groove on the compound centrum. In these features, $\dagger$ Fajumia is more similar to claroteids than the other extant African families. Peyer (1928) concluded that $\dagger$ Fajumia was most similar to Bagridae sensu lato (i.e., including Claroteidae) although he preferred not to assign it explicitly to this family. The illustrations of Peyer (1928) and Stromer (1904) are rather stylized, lacking sutures between bones, and the material we examined is not well preserved, so a better understanding of the two species of $\uparrow$ Fajumia also awaits a planned re-study by another researcher (S. El-Sayed, pers. comm. Feb. 2020). For now, we suggest the relationships of $\uparrow$ Fajumia probably lie with the claroteid catfishes.

$\dagger$ Eopeyeria aegyptiacus was described by Peyer (1928, as $\dagger$ Ariopsis aegyptiacus). Based on the original generic name (which is preoccupied), Peyer presumably saw a resemblance to ariid catfishes. Although the illustrations of the holotype skull (Peyer 1928:pl. V, figs. 1a, 1b) do not show sutures or clear details, it appears that the Weberian apparatus is firmly united with the skull, the aortic canal is enclosed in a tunnel, there is a basioccipital foramen for the aorta, and the dermal ornament is granular, formed of small bumps. All of these features are compatible with this species being an ariid. The anterior end of the skull is missing, so the presence of other ariid features, such as the fenestra between the frontal and lateral ethmoid, and the shape of the mesethmoid, cannot be determined. However, we agree that $†$ Eopeyeria belongs in Ariidae.

The final Eocene Egyptian catfish is $\dagger$ Arius frassi, from the Mokattam Formation. This fish was originally assigned to the genus Arius by Peyer (1928), who argued that the specimen exhibited a morphology similar to that of extant species of this genus. We have not examined any material of this species. Based on the illustrations of (Peyer 1928:pl. VI, figs. 2, 2a, 2b), the fenestra between the lateral ethmoid and frontal appears to be present, the cranial fontanelle and groove penetrate the posterior portion of the mesethmoid, the supraoccipital crest is broad and relatively short, and the dermal ornament is formed of radiating lines of small bumps. In all these features, $\dagger$ Arius frassi is similar to other ariids, and we agree it belongs in that family.

\section{DISCUSSION}

The origins and dispersal of catfishes during the Cenozoic has been studied by, and is of interest to, many researchers. One of the complications of such study is determining the relationships of the fossil material with extant families. Biogeographic reconstructions require a good understanding of the relationships of the groups under study. Without an understanding of how the African fossil remains are related 
to extant groups, they cannot be used to reconstruct the biogeographic history of extant taxa. However, the relationships of African fossil catfishes with modern families have been difficult to determine, or the placements have lacked explicit justification, with some species being moved among different families by subsequent authors. The documentation of the cranial osteology of eight extant families of African catfishes given here now allows us to confidently place at least some fossil catfish remains in extant families based on discrete morphological features. Once we are able to reliably assign fossil remains to families, then we can assess the record of those families in terms of distribution and palaeoenvironment. Of particular interest to us is first to determine which of the Palaeogene taxa noted above are found in marine sediments but belong to freshwater families, and second to document first occurrences of families in Africa.

Fossil catfishes from marine sediments have either been identified as being related to the extant marine family Ariidae [e.g., Gayet and Meunier (2003) allied $\dagger$ Fajumia with Ariidae or Arioida], or alternately, if they were identified as belonging to extant freshwater families, they were assumed to be freshwater forms that were washed into marine environments post-mortem [e.g., $\dagger$ Nigerium was thought by White (1934) to be a freshwater bagrid washed into marine deposits, and based on its presence, he assumed the deposits must be near-shore or estuarine]. These assumptions remove the possibility of using sedimentological evidence as potential support for recognizing extinct marine forms of extant freshwater families.

All three of the Palaeocene species from Sokoto, Nigeria ( $†$ Eomacrones wilsoni, $† ' N i g e r i u m '$ gadense and $\uparrow$ Nigerium wurnoense) were recovered from marine sediments (White 1934). Similarly, the Eocene catfish $\uparrow$ Nigerium tamaguelense was reported from Eocene phosphatic deposits (Longbottom 2010), which indicate marine deposition, and a second Eocene catfish, $†$ Eaglesomia eaglesomei, also was found in marine sediments (White 1926). The relationships of all five of these species are with freshwater families (Bagridae s.s. and Claroteidae). Because the Palaeogene species he reported are associated with freshwater families, White $(1926,1934)$ considered them to have been freshwater forms that were transported to the marine deposits. [Longbottom (2010) did not discuss the palaeoenvironment of $\uparrow N$. tamaguelense.] Although this may be correct, alternately, these catfishes may have been inhabiting coastal marine waters, indicating that claroteid and bagrid catfishes may have included marine or salt-water tolerant species in the Palaeocene and Eocene, with members of the families only becoming confined to fresh waters more recently. In fact, Stewart and Murray (2017) determined that the most probable explanation for the presence of early Oligocene bagrids in the Arabian Plate (reported by Otero and Gayet 2001) was the migration of those fish through brackish waters. As such, the possibility that at least some fossil claroteids and bagrids were adapted to a marine environment should not be dismissed without full examination of the evidence.

With the more confident assignment of the African fossil crania to families, we can now use those fossils to document the first occurrence of specific families in Africa. Gayet (1987) reported remains of bagrids in the freshwater Eocene deposits of Asia (Pakistan). Argyriou et al. (2014), citing Gayet's report, suggested Bagrus (the only extant genus of Bagridae s.s. in Africa) arrived in Africa in the early Miocene. Stewart and Murray (2017) also suggested bagrids (specifically Bagrus) moved into Africa from Asia, probably in the early Miocene. In contrast, Otero and Gayet (2001) suggested that bagrids s.s. arose in Africa and migrated from there into Eurasia in the early Miocene. In both cases, bagrids were considered to be restricted to fresh waters. The confirmation that $\dagger$ Eomacrones wilsoni, from the Palaeocene of Nigeria, belongs in Bagridae s.s., confirms that bagrids were in Africa much earlier than the Miocene. In addition to Eocene African records, bagrids have been reported in Eocene deposits of Europe and Asia (Ng 2003). This distribution of bagrids during the Eocene, when the African landmass had been isolated for over 50 million years, indicates that inferring dispersal through only fresh waters is not tenable. The marine nature of the sediments in which $\dagger$ Eomacrones was found indicate future biogeographic reconstructions need to take into consideration the potential ability of extinct bagrids to at least move through, if not permanently reside in, marine waters.

As Longbottom (2010) noted, assigning catfish fossils to known families has been hindered by a lack of characterization of the extant taxa, which has led to uncertainty in our understanding of the early history of catfishes. With the data presented here, we have filled at least partially some of the gaps in the data for the African catfishes. The documentation of the osteology of the extant catfish crania should allow future fossil finds to be more precisely and accurately placed within extant family groups or recognized as representing extinct families.

\section{CONCLUSIONS}

The assessment of osteological features, whether apomorphies or plesiomorphies, allows fossil catfish material from Africa to be placed in extant families. Crania of the eight catfish families most likely to be found in Cenozoic deposits of Africa can be distinguished by a combination of dermal ornamentation and morphology of individual bones. The ornamentation of the dermal bones has been used in many taxonomic designations of isolated fossil elements, and here it is supported as a useful taxonomic 
character. Some isolated bones such as the mesethmoid and parieto-supraoccipital, appear to be diagnostic of particular taxa because of their unique shapes. Articulated crania, even if incompletely preserved, can be further identified based on the morphology of the cranial fontanelle and associated groove among other features.

The ability to identify fossil catfishes to family based on clear osteological features regardless of the palaeoenvironment inferred by the surrounding sediments allows us to avoid the possibility of circular reasoning. By only using the morphology to determine relationships, the palaeoenvironment can then be used to identify taxa that have potentially moved from marine to freshwaters or vice versa, and provide a better understanding of the evolutionary history of these fishes. Bagrid s.s. catfishes are confirmed to be present in Eocene deposits of Africa. Based on the marine sediments in which they are found, and the presence of Eocene material in Asia and Europe that has been identified as bagrid, we suggest early members of this family had a tolerance of saline waters, or may have inhabited marine environments.

\section{ACKNOWLEDGEMENTS}

We are grateful to the following people who lent specimens or provided access to material in their care: D. Nelson (University of Michigan Museum of Zoology), K. Seymour (Royal Ontario Museum), C. Dillman and C. Dardia (Cornell University Museum of Vertebrates), E.L. Simons, P. Chatrath and G. Gunnell (Duke University Primate Center), and E. Barnard (Natural History Museum, London). Our thanks to two anonymous reviewers for suggestions to improve the manuscript. This research was supported by National Science and Engineering Research Council of Canada Discovery grant 327448 to AMM.

\section{LITERATURE CITED}

Acero, P.A., and R. Betancur-R. 2007. Monophyly, affinities, and subfamilial clades of sea catfishes (Siluriformes: Ariidae). Ichthyological Exploration of Freshwaters 18:133-143.

Argyriou, T., T.D. Cook, A.M. Muftah, P. Pavlakis, N.T. Boaz, and A.M. Murray. 2014. A fish assemblage from an early Miocene horizon from Jabal Zaltan, Libya. Journal of African Earth Sciences 102:86-101. DOI 10.1016/j.jafrearsci.2014.11.008

Al-Rawi, A.H.A. 1966. The development of the Weberian apparatus and the swim bladder in the channel catfish, Ictalurus punctatus (Rafinesque). Ph.D. Thesis, University of Oklahoma, Norman, Oklahoma, USA, 126 pp.

Arratia G. 2003. Catfish head skeleton-an overview; pp. 3-46 in G. Arratia, B.G. Kapoor, M. Chardon, and R. Diogo (eds.). Catfishes. Science Publishers Inc., Enfield, New Hampshire.
Arratia, G., and A. Cione. 1996. The record of fossil fishes of southern South America. Münchner Geowissenschaftliche Abhandlungen, Reihe A, Geologie und Paläontologie 30:9-72.

Ballen, G.A., and M.C.C. de Pinna. 2021. A standardized terminology of spines in the order Siluriformes (Actinopterygii: Ostariophysi). Zoological Journal of the Linnean Society 20:1-25.

Betancur-R, R. 2009. Molecular phylogenetics and evolutionary history of ariid catfishes revisited: a comprehensive sampling. BMC Evolutionary Biology 9:175. DOI:10.1186/1471-2148-9-175

Bleeker, P. 1858a. De visschen van den Indischen Archipel beschreven en toegelicht. Deel I. Siluri. Acta Societatis Regiae Scientiarum Indo-Neêrlandicae 4:1-370.

Bleeker, P. 1858b. De heer Bleeker brengt nog ter tafel het eerste deel van eene ichthyologiae Archipelagi Indici Prodromus. Natuurkundig Tijdschrift voor Nederlandsch Indië 16:38-41.

Bleeker, P. 1862 (1862-1863). Atlas ichthyologique des Indes Orientales Néêrlandaises, Publié sous les Auspices du Gouvernement colonial néêrlandais. Tome II. Siluroïdes, Chacoïdes et Hétérobranchoïdes. Amsterdam: F. Muller 112 pp.

Bonaparte, C.L. 1845. Specchio generale del sistema ittiologico. Atti della sesta Riunione degli Scienziati Italiani 6:386-390.

Boulenger, G.A. 1900. Matériaux pour la faune du Congo. Poissons nouveaux du Congo. Sixième Partie. Mormyres, characins, cyprins, silures, acanthoptérygiens, dipneustes. Annales du Musee du Congo (Ser. Zoology) 1:129-164.

Boulenger, G.A. 1906. Fourth contribution to the ichthyology of Lake Tanganyika.-Report on the collection of fishes made by Dr. W. A. Cunnington during the Third Tanganyika Expedition, 1904-1905. Transactions of the Zoological Society of London 17:537-601.

Boulenger, G.A. 1911. Catalogue of the Fresh-water Fishes of Africa in the British Museum (Natural History), vol. 2. London, 529 pp.

Burchell, W.J. 1822. Travels in the Interior of Southern Africa. London, $582+648$ pp. [not seen]

Cappetta, H. 1972. Les poissons Crétacés et Tertiaires du Bassin des Iullemmeden (Republique du Niger). Palaeovertebrata, Montpellier 5:179-251.

Chardon, M. 1968. Anatomie compare de l'appareil de Weber et des structures connexes chez les Siluriformes. Annales of the Musée royal de l'Afrique centrale, Tervuren, Belgique, Series In. 8ieme, Sciences Zoologiques 169:1-277.

Chardon, M., E. Parmentier, and P. Vandewalle. 2003. Morphology, development and evolution of the Weberian apparatus in catfish; pp. 71-120 in G. Arratia, B.G. Kapoor, M. Chardon, and R. Diogo (eds.). Catfishes. Science Publishers Inc., Enfield, New Hampshire.

Cuvier, G. 1816. Le Règne Animal Distribué d'Après son Organisation pour Servir de Base à l'Histoire Naturelle des Animaux et d'Introduction à l'Anatomie comparée. Les reptiles, les Poissons, les Mollusques et les Annélides. Edition 1. vol. 2. Chez Deterville, Paris, 532 pp. 
Cuvier, G., and A. Valenciennes. 1840. Histoire Naturelle des Poissons. Tome quinzième. Suite du livre dix-septième. Vol. 15: Siluroïdes. Paris: Chez Ch. Pitois, 540 pp.

de Pinna, M.C.C. 1998. Phylogenetic relationships of Neotropical Siluriformes (Teleostei: Ostariophysi): historical overview and synthesis of hypotheses; pp. 279-330 in L.E. Malabarba, R.E. Reis, R.P. Vari, C.A.S. Lucena, and Z.M.S. Lucena (eds.). Phylogeny and Classification of Neotropical Fishes. Museu de Ciencias e Tecnologia, PUCRS, Porto Alegre, Brazil.

de Vos, L. 1995. A systematic revision of the African Schilbeidae (Teleostei, Siluriformes) with an annotated bibliography. Annales Sciences Zoologiques, Musée Royal de l'Afrique Centrale, Tervuren, Belgique 271:1-450.

Diogo, R. 2003. Anatomy, phylogeny and taxonomy of Amphiliidae; pp. 401-438 in G. Arratia, B.G. Kapoor, M. Chardon, and R. Diogo (eds.). Catfishes. Science Publishers Inc., Enfield, New Hampshire.

Diogo, R. 2005. Morphological Evolution, Aptations, Homoplasies, Constraints and Evolutionary Trends: Catfishes as a Case Study on General Phylogeny and Macroevolution. Science Publishers Inc., Enfield, New Hampshire. 491 pp.

Diogo, R., C. Oliveira, and M. Chardon. 2000. On the anatomy and function of the cephalic structures in Phractura (Siluriformes: Amphiliidae), with comments on some striking homoplasies occurring between the Doumeinae and some loricaroid catfishes. Belgian Journal of Zoology 130:117-130.

Duméril, A.M.C. 1856. Ichthyologie analytique ou classification des poissons, suivant la méthode naturelle, à l'aide de tableaux synoptiques. Mémoires de l'Académie des Sciences: tirés des registres de cette Académie 27:1-507. [not seen]

El-Sayed, S., M.A. Kora, H.M. Sallam, K.M. Claeson, E.R. Seiffert, and M.S. Antar. 2017. A new genus and species of marine catfishes (Siluriformes; Ariidae) from the upper Eocene Birket Qarun Formation, Wadi El-Hitan, Egypt. PLoS One 12: e0172409. DOI 10.1371/journal.pone.0172409

El-Sayed, S., A.M. Murray, M.A. Kora, G.A. Abu El-Kheir, M.S. Antar, E.R. Seiffert, and H.M. Sallam. 2020. Oldest record of African Bagridae and evidence from catfishes for a marine influence in the late Eocene Birket Qarun Locality 2 (BQ-2), Fayum Depression, Egypt. Journal of Vertebrate Paleontology e1780248 (19 pages). DOI 10.1080/02724634.2020.1780248

Fricke, R., W.N. Eschmeyer, R. van der Laan (eds.). 2020. Eschmeyer's Catalog of Fishes: Genera, Species, References. Electronic version accessed April 20, 2020. (http://researcharchive. calacademy.org/research/ichthyology/catalog/fishcatmain.asp).

Froese, R., and D. Pauly (eds). 2020. FishBase. World Wide Web electronic publication. www.fishbase.org, version (12/2020).

Gayet, M. 1987. Lower vertebrates from the early-middle Eocene Kuldana formation of Kohat (Pakistan): Holostei and Teleostei. Contributions from the Museum of Paleontology, University of Michigan 27:151-168.

Gayet, M., and F.J. Meunier. 2003. Palaeontology and palaeobiogeography of catfishes; pp. 491-522 in: G. Arratia, B.G. Kapoor, M. Chardon, and R. Diogo (eds.). Catfishes. Science Publishers Inc., Enfield, New Hampshire.
Gayet, M., and W. Van Neer. 1990. Caractères diagnostiques des épines de quelques silures africains. Journal of African Zoology - Revue de Zoologie Africaine 104:241-252.

Geoffroy St. Hilaire, E. 1809. Poissons du Nil, de la mer Rouge et de la Méditerranée. Description de l'Egypte ou recueil des observations et des recherches qui ont été faites en Égypte pendant l'expedition de l'Armée français, publié par les ordres de sa Majesté-L'Empereur Napoléon le Grand. Histoire Naturelle. Poissons. Vol. 1:1-52. Imprimerie Impériale, Paris. [not seen]

Geoffroy St. Hilaire, E. 1827. Suite de l'histoire des poissons du Nil. Description de l'Egypte ou recueil des observations et des recherches qui ont été faites en Égypte pendant l'expedition de l'Armée français, publié par les ordres de sa Majesté-L'Empereur Napoléon le Grand. Vol. 1:265-310. Imprimerie Impériale, Paris.

Gianferrari, L. 1923. Uegitglanis zammaronoi un nuovo siluride cieco africano. Atti della Società Italiana di Scienze Naturali di Milano 62:1-3. [not seen]

Gill, T.N. 1861. Catalogue of the fishes of the eastern coast of North America, from Greenland to Georgia. Proceedings of the Academy of Natural Sciences of Philadelphia 13(suppl.):1-63.

Glaw, F., and M. Vences. 1994. A Field Guide to the Amphibians and Reptiles of Madagascar. Second Edition Including Mammals and Freshwater Fish. Köln, Germany: Privately published, 480 pp. ISBN 3-929449-01-3

Gmelin, J.F. 1789. Caroli a Linné ... Systema Naturae per regna tria naturae, secundum classes, ordines, genera, species; cum characteribus, differentiis, synonymis, locis. Editio decimo tertia, aucta, reformata. 3 vols. in 9 parts. Lipsiae, 1788-93. v. 1 (pt 3):1033-1516.

Greenwood, P.H. 1958. A new genus and species of cat-fish (Pisces, Clariidae) from the deeper waters of Lake Victoria. Annals and Magazine of Natural History (Series 13) 1:321-325.

Greenwood, P.H. 1972. New fish fossils from the Pliocene of Wadi Natrun, Egypt. Journal of Zoology, London 168: 503-519.

Greenwood, P.H, and G.J. Howes. 1975. Neogene fossil fishes from the Lake Albert-Lake Edward Rift (Zaire). Bulletin of the British Museum (Natural History) Geology 26:71-127.

Günther, A. 1865. Pisces. The record of zoological literature. Zoological Record 1 (for 1864):133-188.

Günther, A. 1867. New fishes from the Gaboon and Gold Coast. Annals and Magazine of Natural History (Series 3) 20:110-117.

Günther, A. 1873. New fishes from Angola. Annals and Magazine of Natural History (Series 4) 12:142-144.

Hora, S.L. 1921. Fish and fisheries of Manipur with some observations on those of the Naga Hills. Records of the Indian Museum 22:165-214.

Jackson, P.B.N. 1959. Revision of the clariid catfishes of Nyasaland, with a description of a new genus and seven new species. Proceedings of the Zoological Society of London 132:109-128.

Kailola, P.J. 1990. The catfish family Ariidae (Teleostei) in New Guinea and Australia: relationships, systematics and zoogeography. Ph.D. thesis, University of Adelaide, Adelaide, Australia, 541 pp. 
Kailola, P.J. 2004. A phylogenetic exploration of the catfish family Ariidae (Otophysi: Siluriformes). The Beagle, Records of the Museums and Art Galleries of the Northern Territory 20:87-166.

Kner, R. 1855. Über ein neues Genus aus der Familie der Welse, Siluroidei. Sitzungsberichte der Kaiserlichen Akademie der Wissenschaften. Mathematisch-Naturwissenschaftliche Classe v. 17:313-316.

Lacepède, B.G.E. 1803. Histoire Naturelle des Poissons. Vol. 5. Chez Plassan, Imprimeur-Libraire, Paris. 803 pp.

Leach, W.E. 1818. Fishes; pp. 409-410 in J.K. Tuckey (ed.). A general notice of the animals taken by Mr. John Cranch, during the expedition to explore the source of the River Zaire. Appendix 4. Narrative of an expedition to explore the River Zaire, usually called the Congo, in south Africa, in 1816. John Murray, London.

Longbottom, A. 2010. A new species of the catfish Nigerium from the Palaeogene of the Tilemsi Valley, Republic of Mali. Palaeontology 53:571-594.

Mahy, G.J.D. 1974. Ostéologie descriptive et comparée de la famille des Malapteruridae (Pisces: Ostariophysi). Musée royal de l'Afrique centrale Tervuren, série in 8ieme 209: 52 pp.

Marceniuk, A.P, and N.A. Menezes. 2007. Systematics of the family Ariidae (Ostariophysi, Siluriformes), with a redefinition of the genera. Zootaxa 1416:1-126.

Marceniuk, A.P., N.A. Menezes, and M.R. Britto. 2012. Phylogenetic analysis of the family Ariidae (Ostariophysi: Siluriformes), with a hypothesis on the monophyly and relationships of the genera. Zoological Journal of the Linnean Society 165:534-669.

Mo, T. 1991. Anatomy, Relationships and Systematics of the Bagridae (Teleostei: Siluroidei): With a Hypothesis of Siluroid Phylogeny. Koenigstein, Germany: Koeltz Scientific Books, 216 pp.

Moore, A., T. Blenkinsop, and F.(W.) Cotterill. 2009. Southern African topography and erosion history: plumes or plate tectonics? Terra Nova 21: 310-315. DOI 10.1111/j.13653121.2009.00887.x

Murray, A.M. 2000. Review of the Palaeozoic, Mesozoic and Early Cenozoic fishes of Africa. Fish and Fisheries 1:111-145.

Murray, A.M., and L.A. Budney. 2003. A new species of catfish (Claroteidae, Chrysichthys) from an Eocene crater lake in East Africa. Canadian Journal of Earth Sciences 40:983-993.

Murray, A.M., and R.B. Holmes. 2021. A new species of claroteid catfish (Siluriformes: Claroteidae) from the Eocene of Egypt, (Africa) indicates continental differences in tempo of catfish evolution Journal of Vertebrate Paleontology e1979021 (11 pages). DOI 10.1080/02724634.2021.1979021

Murray, A.M., T.D. Cook, Y.S. Attia, P. Chatrath, and E.L. Simons. 2010. A freshwater ichthyofauna from the late Eocene Birket Qarun Formation, Fayum, Egypt. Journal of Vertebrate Paleontology 30:665-680.

Nelson, J.S., T.C. Grande, and M.V.H. Wilson. 2016. Fishes of the World. Fifth edition. John Wiley and Sons, Hoboken, New Jersey. 707 pp.
Ng, H.H. 2003. Phylogeny and systematics of Bagridae; pp. 439-463 in G. Arratia, B.G. Kapoor, M. Chardon, and R. Diogo (eds.). Catfishes. Science Publishers Inc., Enfield, New Hampshire.

Ng, H.H., and J.S. Sparks. 2005. Revision of the endemic Malagasy catfish family Anchariidae (Teleostei: Siluriformes), with descriptions of a new genus and three new species. Ichthyological Exploration of Freshwaters 16:303-323.

Niebuhr, C. 1775. Descriptiones Animalium Avium, Amphibiorum, Piscium, Insectorum, Vermium; Quae in Itinere Orientali Observavit Petrus Forskål. Post Mortem Auctoris Edidit Carsten Niebuhr. Hauniae. 164 pp. [not seen]

Norris, S.M. 2002. A revision of the African electric catfishes, family Malapteruridae (Teleostei, Siluriformes), with erection of a new genus and descriptions of fourteen new species, and an annotated bibliography. Annales Sciences Zoologiques, Musée Royal de l'Afrique Centrale Tervuren 289:5-155.

Oken, L. 1817. Isis (Oken). Vol. 1. Jena, 1779-1782.

Otero, O., and M. Gayet. 2001. Palaeoichthyofaunas from the lower Oligocene and Miocene of the Arabian Plate: palaeoecological and palaeobiogeographical implications. Palaeogeography, Palaeoclimatology, Palaeoecology 165:141-169.

Otero, O., A. Likius, P. Vignaud, and M. Brunet. 2007. A new claroteid catfish (Siluriformes) from the upper Miocene of Toros-Menalla, Chad: Auchenoglanis soye, sp. nov. Journal of Vertebrate Paleontology 27:285-294.

Otero, O., A. Pinton, H.T. Mackaye, A. Likius, P. Vignaud, and M. Brunet. 2009a. First description of a Pliocene ichthyofauna from Central Africa (site KL2, Kolle area, Eastern Djurab, Chad): What do we learn? Journal of African Earth Sciences 54:62-74.

Otero, O., A. Pinton, H.T. Mackaye, A. Likius, P. Vignaud, and M. Brunet. 2009b. Fishes and palaeogeography of the African drainage basins: relationships between Chad and neighbouring basins throughout the Mio-Pliocene. Palaeogeography, Palaeoclimatology, Palaeoecology 274:134-139

Otero, O., A. Pinton, H.T. Mackaye, A. Likius, P. Vignaud, and M. Brunet. 2010. The fish assemblage associated with the late Miocene Chadian hominid (Toros-Menalla, Western Djurab) and its palaeoenvironmental significance. Palaeontographica, Abt. A: Palaeozoology - Stratigraphy 292:21-51.

Otero, O., A. Pinton, H. Cappetta, S. Adnet, X. Valentin, M. Salem, and J.J. Jaeger. 2015. A fish assemblage from the middle Eocene from Libya (Dur At-Talah) and the earliest record of modern African fish genera. PLoS One 10: e0144358. DOI 10.1371/journal.pone.0144358

Peyer, B. 1928. Ergebnisse der Forschungsreisen Prof. E. Stromers in den Wüsten Ägyptens. V. Tertiäre Wirbeltiere. 2. Die Welse des ägyptischen Alttertiärs nebst einer kritischen Übersicht über alle fossilen Welse. Abhandlungen der Bayerischen Akademie der Wissenschaften Mathematisch - naturwissenschaftliche Abteilung 32:1-61.

Pinton, A., O. Otero, A. Likius, H.T. Mackaye, P. Vignaud, and M. Brunet. 2011. Giants in a minute catfish genus: first description of fossil Mochokus (Siluriformes, Mochokidae) in 
the late Miocene of Chad, including M. gigas, sp. nov. Journal of Vertebrate Paleontology 31:22-31.

Poll, M. 1942. Description d'un genre nouveau de Clariidae originaire du Congo belge. Revue de Zoologie et de Botanique Africaines 36:94-100.

Poll, M. 1943. Description du Tanganikallabes mortiauxi, gen. nov., sp. n., de la famille des Clariidae. Revue de Zoologie et de Botanique Africaines 37:126-133.

Poll, M. 1977. Les genres nouveaux Platyallabes et Platyclarias comparés au genre Gymnallabes Gthr. Synopsis nouveau des genres de Clariidae. Bulletin de la Classe des Sciences, Académie Royale de Belgique (Serie 5) 63:122-149.

Pratt, M.J., M.E. Wysession, G. Aleqabi, D.A. Wiens, A.A. Nyblade, P. Shore, G. Rambolamanana, F. Andriampenomanana, T. Rakotondraibe, R.D. Tucker, G. Barruol, and E. Rindraharisaona. 2017. Shear velocity structure of the crust and upper mantle of Madagascar derived from surface wave tomography. Earth and Planetary Science Letters 458:405-417.

Regan, C.T. 1911. The classification of the teleostean fishes of the order Ostariophysi - 2. Siluroidea. Annals and Magazine of Natural History 8:553-577. DOI 10.1080/00222931108693067

Regan, C.T. 1912. Pisces 1911. Zoological Record 48:1-47.

Rüppell, W.P.E.S. 1829 (1829-1835). Beschreibung und Abbildung mehrerer neuer Fische, im Nil entdeckt. Brönner, Frankfurt am Main. 12 pp.

Rüppell, W.P.E.S. 1832. Fortsetzung der Beschreibung und Abbildung mehrerer neuer Fische, im Nil entdeckt. Brönner, Frankfurt am Main. 14 pp.

Samonds, K.E., L.R. Godfrey, J.R. Ali, S.M. Goodman, M. Vences, M.R. Sutherland, M.T. Irwin, and D.W. Krause. 2012. Spatial and temporal arrival patterns of Madagascar's vertebrate fauna explained by distance, ocean currents, and ancestor type. Proceedings of the National Academy of Sciences 109:53525357. DOI 10.1073/pnas.1113993109

Scopoli, J.A. 1777. Introductio ad Historiam Naturalem, Sistens Genera Lapidum, Plantarum et Animalium Hactenus Detecta, Caracteribus Essentialibus Donata, in Tribus Divisa, Subinde ad Leges Naturae. Apud Wolfgangum Gerle, Prague. 506 pp.

Seegers, L. 2008. The Catfishes of Africa. Aqualog Verlag A.C.S. GmBH, Rodgau, Germany. 604 pp.

Skelton, P. 2007. New species of the amphiliid catfish genera Amphilus, Doumea and Phractura and the taxonomy of Paramphilius from West Central Africa (Siluriformes, Amphiliidae). Zootaxa 1578:41-68.

Skelton, P.H., L. Risch, and L. de Vos. 1984. On the generic identity of the Gephyroglanis catfishes from Southern Africa (Pisces, Siluroidei, Bagridae). Revue de Zoologie Africaine 98:338-372.

Smith, A.G., D.G. Smith, and B.M. Funnell. 1994. Atlas of Mesozoic and Cenozoic Coastlines. Cambridge University Press, Cambridge. 99 pp.

Stewart, K.M. 2001. The freshwater fish of Neogene Africa (Miocene-Pleistocene): systematics and biogeography. Fish and Fisheries 2:177-230.
Stewart, K.M. 2003. Fossil fish remains from Mio-Pliocene deposits at Lothagam, Kenya; pp. 75-110 in M.G. Leakey, and J.M. Harris (eds.) Lothagam: The Dawn of Humanity in Eastern Africa. Columbia University Press, New York.

Stewart, K.M., and A.M. Murray. 2017. Biogeographic implications of fossil fishes from the Awash River, Ethiopia. Journal of Vertebrate Paleontology 37: e1269115 (16 pages). DOI 10.1080/02724634.2017.1269115.

Stewart, K.M., and A.M. Murray. 2020. Pliocene and Pleistocene fishes from Gona, Ethiopia: inferences for reconstructing freshwater paleoecology. Journal of Vertebrate Paleontology e1819302 (12 pages). DOI 10.1080/02724634.2020.1819302

Stewart, K.M., O.M. Kovalchuk, O.A. Goskova, and N.V. Pogodina. 2019. Late Pleistocene fish remains from the Rurubu River, Tanzania. Journal of Vertebrate Paleontology e1639055 (8 pp.) DOI 10.1080/02724634.2019.1639055

Steindachner, F. 1880. Ichthyologische Beiträge (IX). I. Über eine Sammlung von Flussfischen von Tohizona auf Madagascar. II. Über zwei neue Agonus-Arten aus Californien. III. Über einige Fischarten aus dem nördlichen Japan, gesammelt von Professor Dybowski. Sitzungsberichte der Kaiserlichen Akademie der Wissenschaften. Mathematisch-Naturwissenschaftliche Classe 2:238-266.

Stromer, E. 1904. Nematognathi aus dem Fajûm und dem Natronthale in Aegypten. Neues Jahrbuck für Mineralogie, Geologie und Paleöntologie 1:1-7.

Sullivan, J.P., J.G. Lundbert, and M. Hardman. 2006. A phylogenetic analysis of the major groups of catfishes (Teleostei: Siluriformes) using rag1 and rag2 nuclear gene sequences. Molecular Phylogenetics and Evolution 41:636-662.

Tampanila, L., E.M. Roberts, M.L. Bouare, F. Sissoko, and M.A. O'Leary. 2008. Phosphate taphonomy of bone and coprolite conglomerates: a case study from the Eocene of Mali, NW Africa. Palaios 23:139-152.

Thunberg, C.P. 1787. Museum D. D. [Docente Deo] Museum Naturalium Academiae Upsaliensis. Cujus partem primam consensu exp. Fac. Med. Upsal. Praeside Carol. Pet. Thunberg, Publico examini proponit, Fridericus Wilhelm. Radloff, Stockholmiensis. In auditorio Gust. Maj. d. XIV. April. MDCCLXXXVII. H. A. M. S. Upsaliae Typis Edmannianis, 16 pp. [not seen]

van der Laan, R. 2018. Family-group names of fossil fishes. European Journal of Taxonomy 466:1-167. DOI 10.5852/ ejt.2018.466

van der Laan, R., W.N. Eschmeyer, and R. Fricke. 2014. Familygroup names of Recent fishes. Zootaxa 3882:1-230. DOI 10.11646/zootaxa.3882.1.1

Walsh, S.J., L.J. Chapman, A.E. Rosenberger, and C.A. Chapman. 2000. Redescription of Amphilius jacksonii (Siluriformes: Amphiliidae) with habitat and life-history notes. Ichthyological Explorations of Freshwaters 11:163-174.

Wang, J., B. Lu, R. Zan, J. Chai, W. Ma, W. Jin, R. Duan, J. Luo, R.W. Murphy, H. Xiao, and Z. Chen. 2016. Phylogenetic relationships of five Asian schilbid genera including Clupisoma (Siluriformes: Schilbeidae). PLoS One 11: e0145675. DOI 10.1371/journal.pone.0145675 
Weiler, W. 1935. Ergebnisse der Forschungsreisen Prof. E. Stromers in den Wüsten Ägyptens. II. Wirbeltierreste der Baharîje-Stufe (unterstes Cenoman). 16. Neue Untersuchungen an den Fischresten. Abhandlungen der Bayerischen Akademie der Wissenschaften Mathematisch-naturwissenschaftliche Abteilung Neue Folge 32:5-57.

White, E.I. 1926. Eocene fishes from Nigeria. Bulletin, Geological Survey of Nigeria 10:1-87.

White, E.I. 1934. Fossil fishes of Sokoto Province. Bulletin, Geological Survey of Nigeria 14:1-78.

White, E.I. 1936 [1937]. The name of a fossil cat-fish. The Geological Magazine 74:144.

Whitley, G.P. 1940. The Nomenclature Zoologicus and some new fish names. The Australian Naturalist 10:241-243.

Whitley, G.P. 1947. New sharks and fishes from Western Australia. Part 3. Australian Zoologist 11:129-150.

Wright, J.J. 2017. A new diminutive genus and species of catfish from Lake Tanganyika (Siluriformes: Clariidae). Journal of Fish Biology 91:789-805.
Appendix 1. List of comparative material examined.

Recent skeletal material:

Ariidae: Ariopsis felis 1 specimen ROM R1843, 1 specimen UAMZ uncatalogued

Bagridae: Bagrus bayad 1 specimen CU 94686; Bagrus docmac 1 specimen CU 94690, 1 specimen UMMZ 187332-S

Clariidae: Clarias gariepinus 4 specimens UAMZ uncatalogued;

C. batrachus 1 specimen UAMZ uncatalogued

Claroteidae: Auchenoglanis occidentalis 1 specimen CU 90623;

Chrysichthys auratus 1 specimen UMMZ 210275-S; Chrysichthys

mabusi 1 specimen CU 91487; Clarotes laticeps 3 specimens

UAMZ uncatalogued

Malapteruridae: Malapterurus electricus 1 specimen UAMZ uncatalogued

Mochokidae: Synodontis sp. 2 specimens UAMZ uncatalogued; Synodontis cf. S. petricola 1 specimen UAMZ uncatalogued; Synodontis acanthomias 1 specimen UAMZ F9048; Synodontis angelicus 1 specimen UAMZ uncatalogued; Synodontis schall 1 specimen CU 94694

Plotosidae: Plotosus lineatus 1 specimen UAMZ uncatalogued Schilbeidae: Schilbe intermedius 1 specimen CU 94688; Schilbe mystus 1 specimen CU 90830

Fossil material:

$\dagger$ Eaglesomia eaglesomei NHMUK P.11944 (holotype), NHMUK P.11945 Eocene, Ameki, Nigeria

$\dagger$ Eomacrones wilsoni NHMUK P. 18800 (holotype) Palaeocene,

Sokoto Nigeria

$\dagger$ Fajumia sp. NHMUK P.10245; DPC 4150 Eocene, Fayum, Egypt

$\dagger$ Fajumia schweinfurthi NHMUK P.10250, NHMUK P.10251

Eocene, Fayum, Egypt

†Fajumia cf. F. stromeri NHMUK P.56470; DPC 3645 Eocene, Fayum, Egypt

$\dagger$ Nigerium gadense NHMUK P.18846(holotype) Palaeocene, Sokoto, Nigeria;

$\uparrow$ Nigerium tamaguelense NHMUK P.66679-P.66682, NHMUK

P. 66683 (holotype), NHMUK P.66686, NHMUK P.66688, NHMUK P.66690-P.66692, NHMUK P.66697, NHMUK P.66700, Eocene, Mali

$\uparrow$ Nigerium wurnoense NHMUK P.18844 (holotype), NHMUK

P.18845 (paratype), Palaeocene, Sokoto, Nigeria

†Socnopaea sp. NHMUK P.10241, P.10242 Eocene, Fayum, Egypt

†Socnopaea grandis NHMUK P.10258, Eocene, Fayum, Egypt 


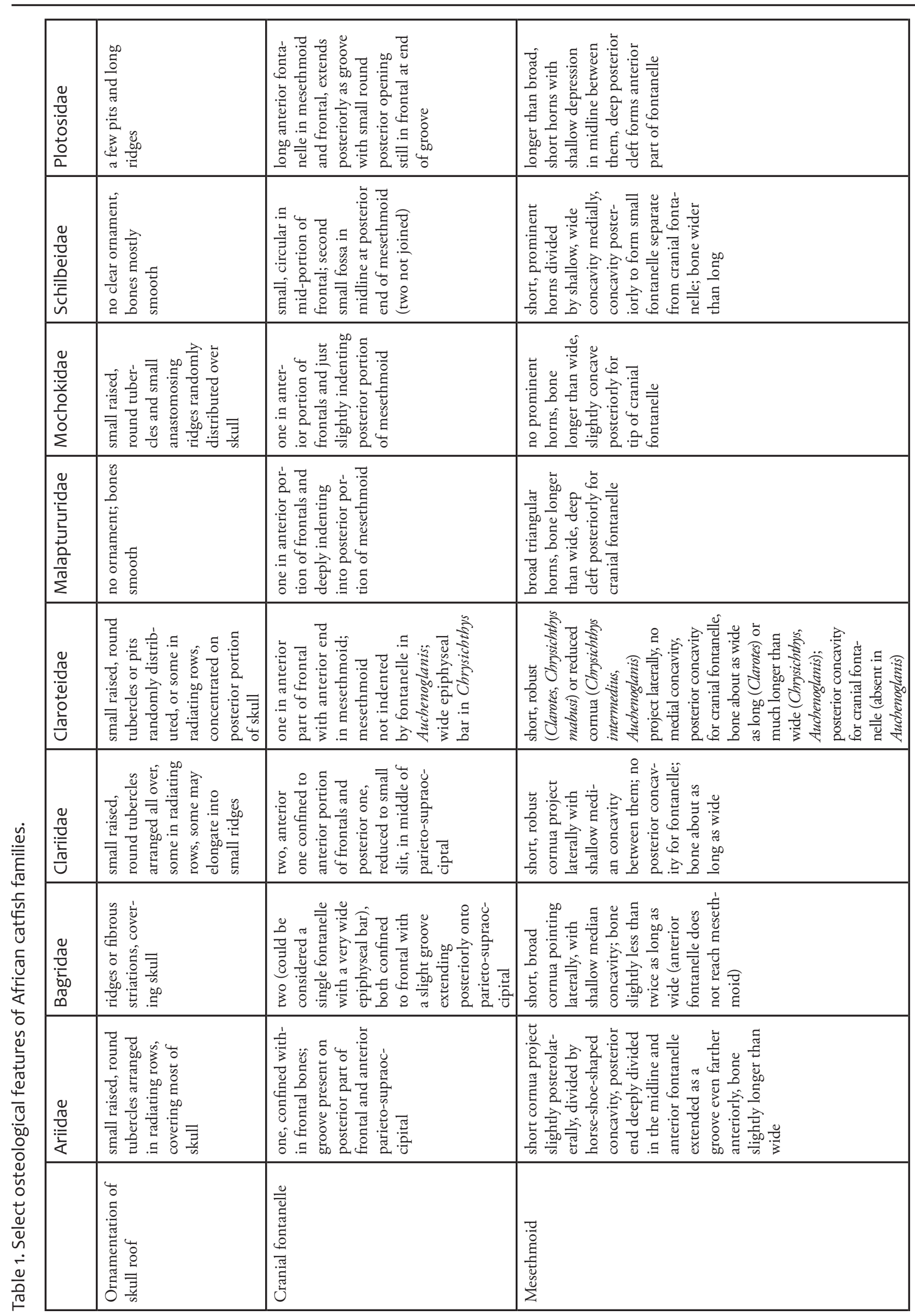




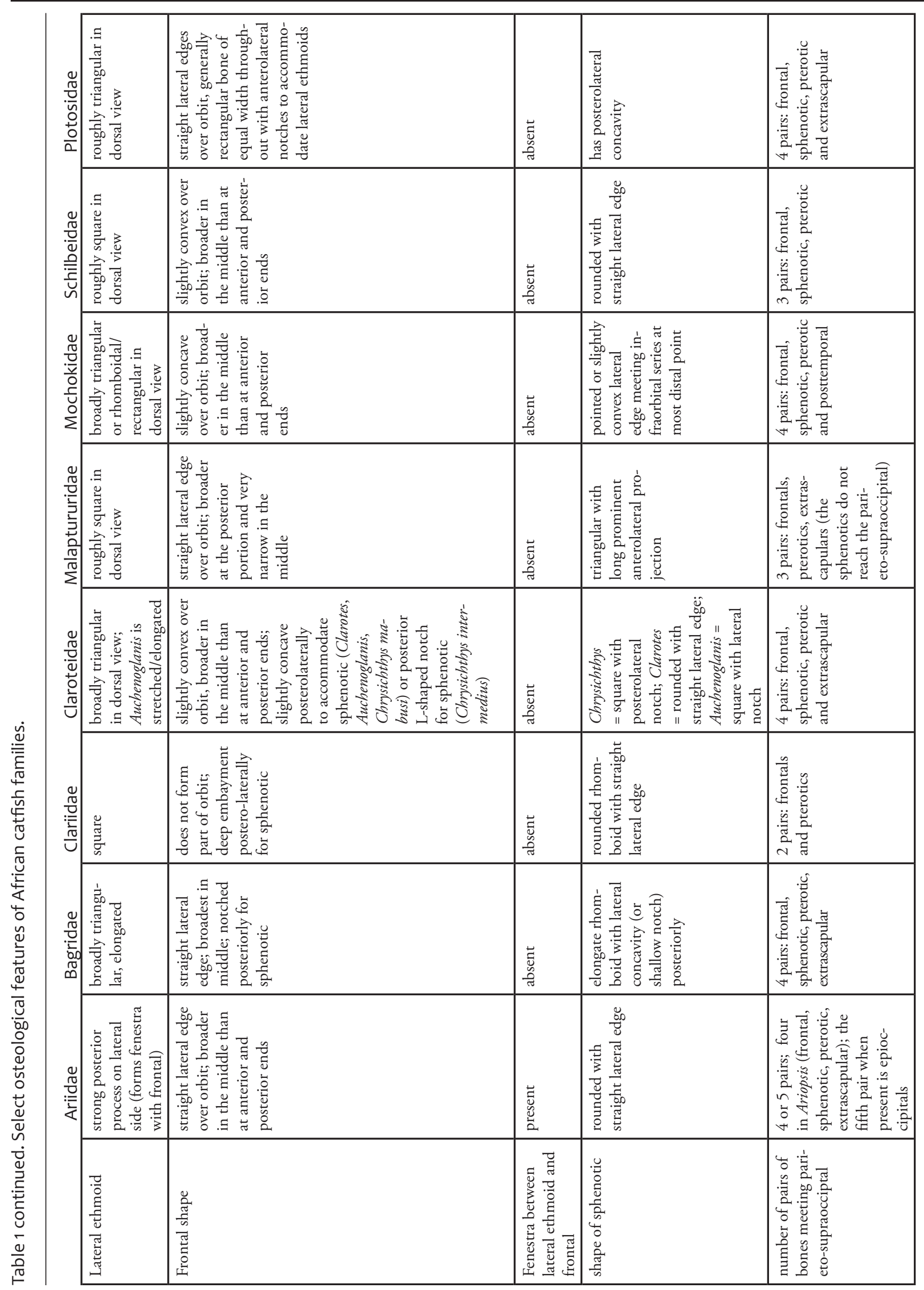




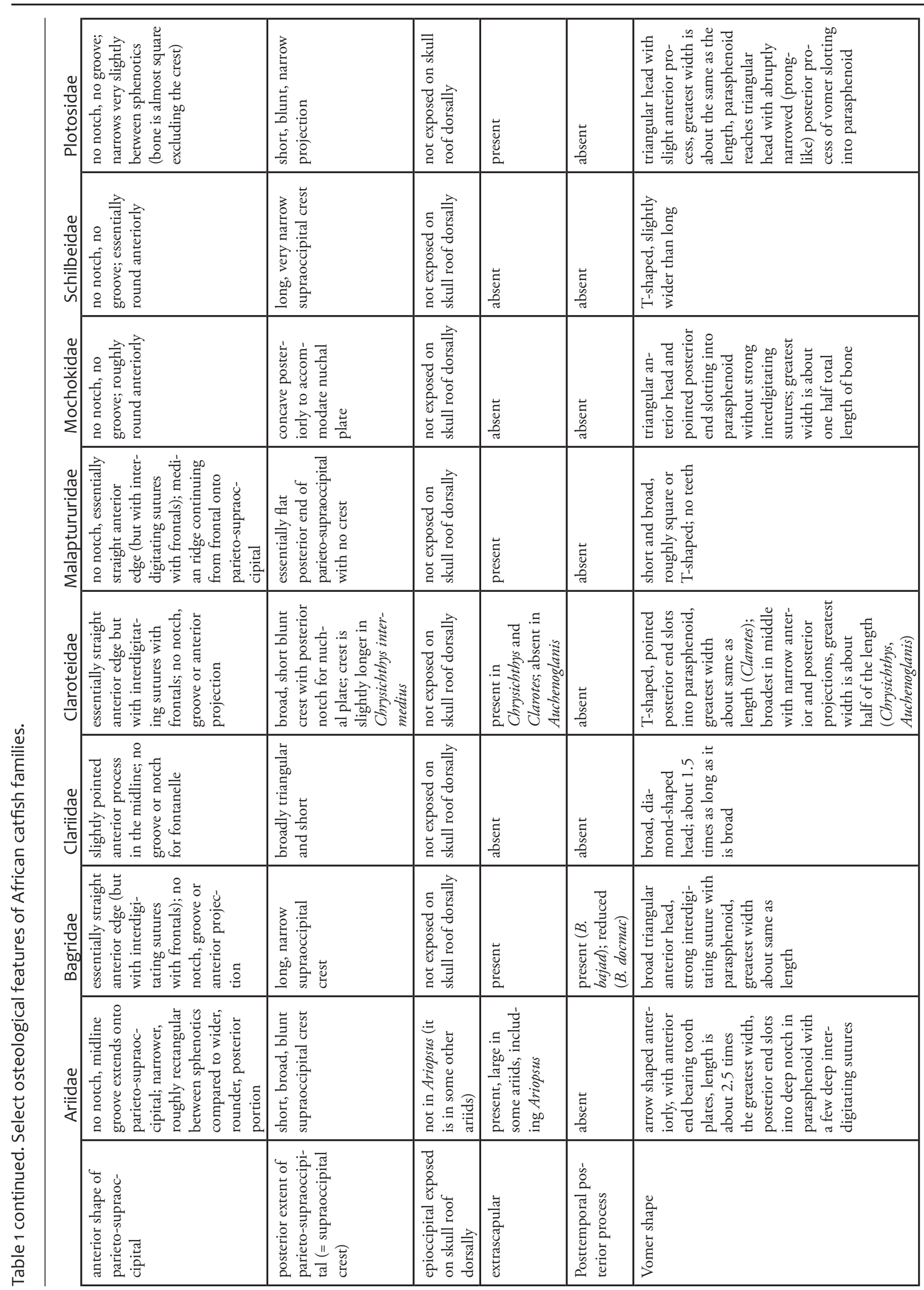




\begin{tabular}{|c|c|c|c|c|c|c|c|c|c|}
\hline $\begin{array}{l}0 \\
\frac{\pi}{n} \\
\frac{0}{n} \\
0 \\
\frac{0}{\alpha}\end{array}$ & 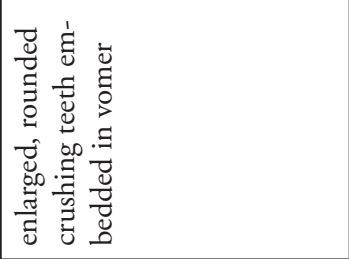 & 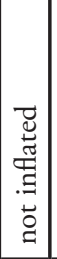 & 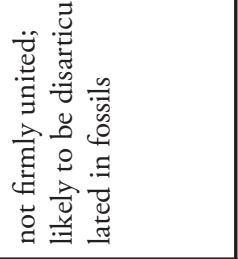 & $\begin{array}{l}\overrightarrow{\tilde{J}} \\
\text { on } \\
\text { त्र }\end{array}$ & $\begin{array}{l}\overrightarrow{\tilde{J}} \\
\text { on } \\
\text { त्र }\end{array}$ & 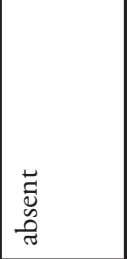 & 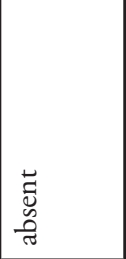 & 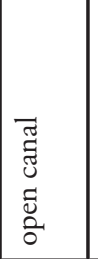 & 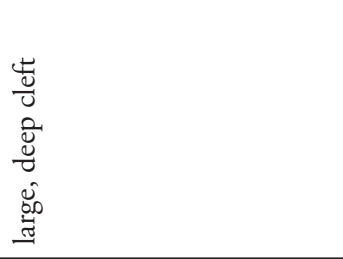 \\
\hline 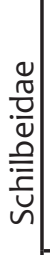 & 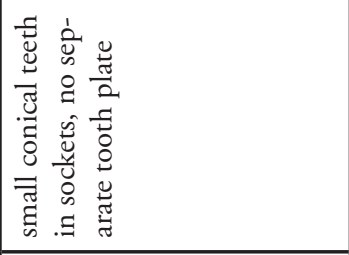 & 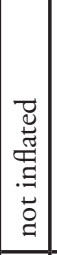 & 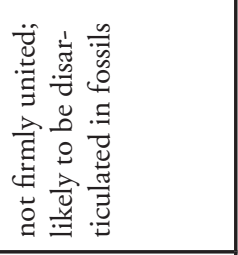 & $\begin{array}{l}\text { 苟 } \\
\text { مै } \\
\text { त्र }\end{array}$ & 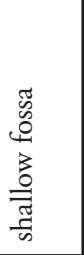 & $\begin{array}{l}\overrightarrow{\tilde{J}} \\
\text { ते } \\
\text { त्र }\end{array}$ & 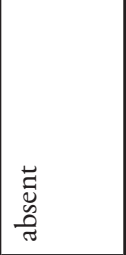 & 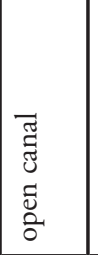 & 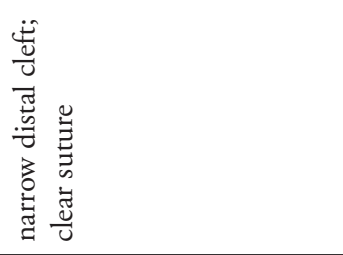 \\
\hline $\begin{array}{l}\frac{0}{\pi} \\
\frac{\pi}{y} \\
\frac{\mathbf{v}}{\mathrm{y}} \\
\stackrel{0}{\Sigma}\end{array}$ & 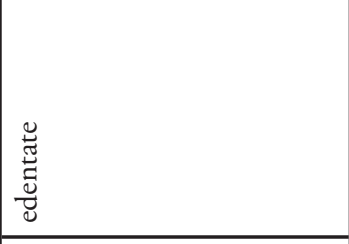 & 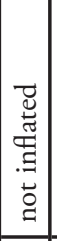 & 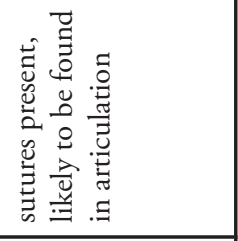 & 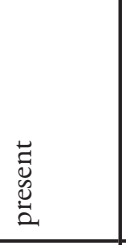 & 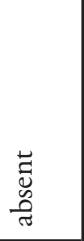 & 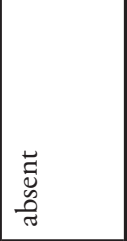 & 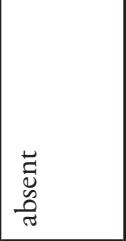 & 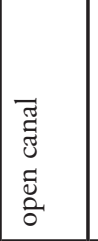 & 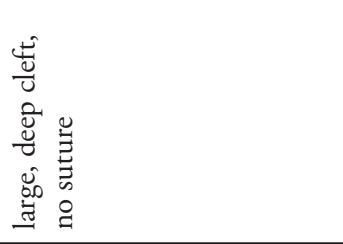 \\
\hline $\begin{array}{l}\frac{0}{\pi} \\
\frac{\pi}{0} \\
\frac{0}{3} \\
\frac{2}{2} \\
0 \\
\frac{0}{0} \\
\frac{\pi}{20}\end{array}$ & 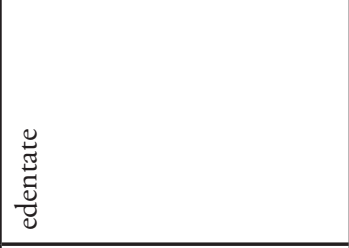 & 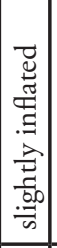 & 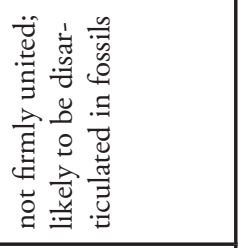 & 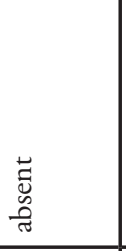 & 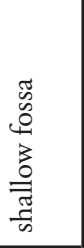 & 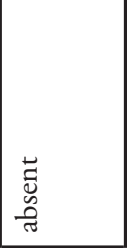 & 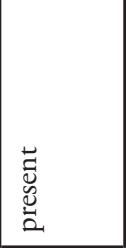 & 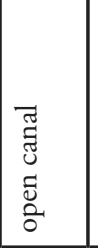 & 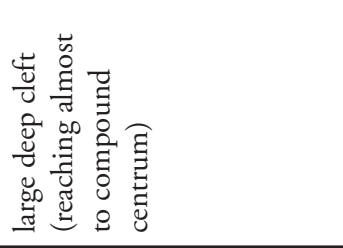 \\
\hline & 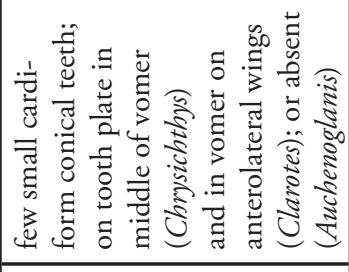 & 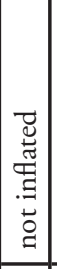 & 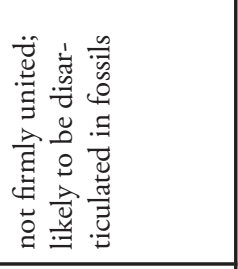 & $\begin{array}{l}\text { 苟 } \\
\text { مै } \\
\end{array}$ & 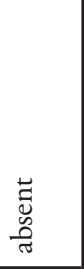 & 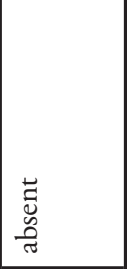 & 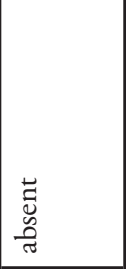 & 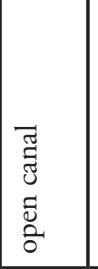 & 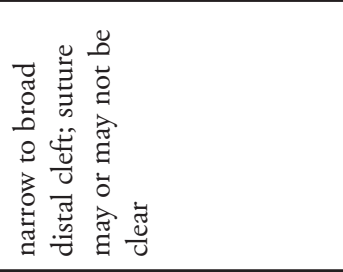 \\
\hline $\begin{array}{l}\frac{0}{\pi} \\
: \frac{0}{\frac{0}{\tau}} \\
\frac{\pi}{U}\end{array}$ & 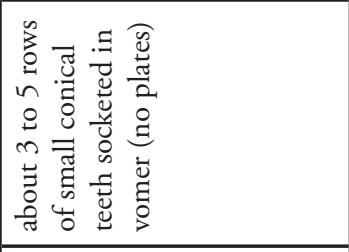 & 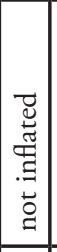 & 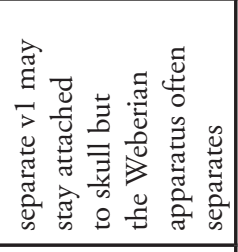 & $\begin{array}{l}\tilde{\vec{U}} \\
\text { U. } \\
\stackrel{\pi}{0}\end{array}$ & 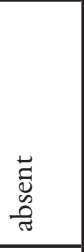 & 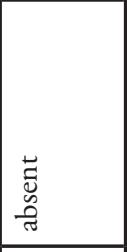 & $\begin{array}{l}\overrightarrow{\tilde{U}} \\
\text { तै } \\
\text { ते } \\
\end{array}$ & 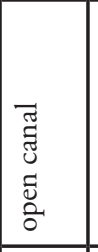 & 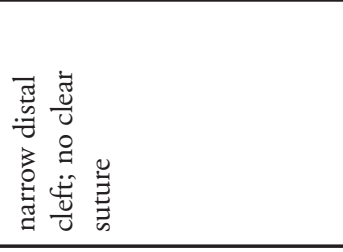 \\
\hline $\begin{array}{l}\frac{0}{\pi} \\
\frac{\pi}{0} \\
\frac{0}{00} \\
\pi \\
\infty\end{array}$ & 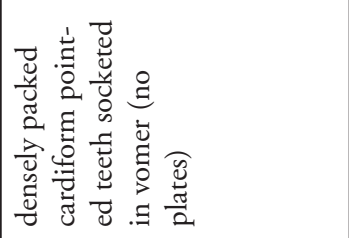 & 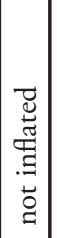 & 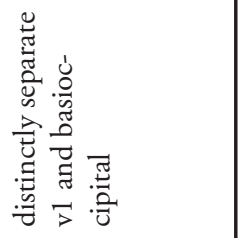 & 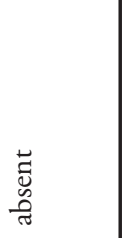 & 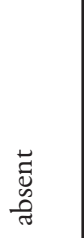 & 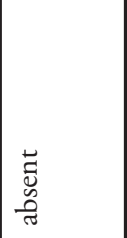 & 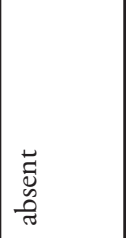 & 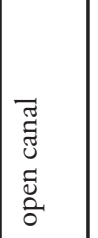 & 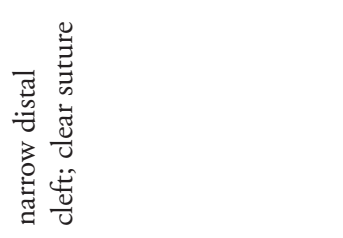 \\
\hline $\begin{array}{l}\frac{\pi}{\pi} \\
: \frac{\pi}{2} \\
:\end{array}$ & 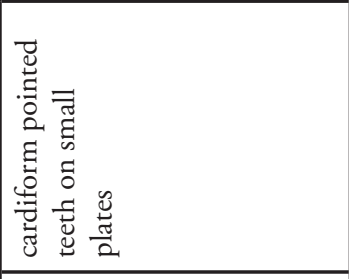 & 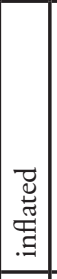 & 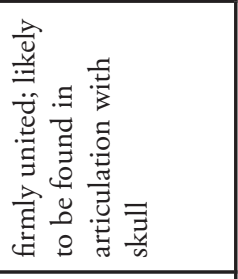 & 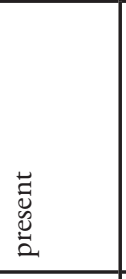 & 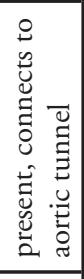 & 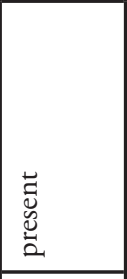 & $\begin{array}{l}\overrightarrow{\tilde{U}} \\
\text { ते } \\
\text { ते } \\
\end{array}$ & 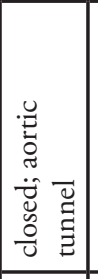 & 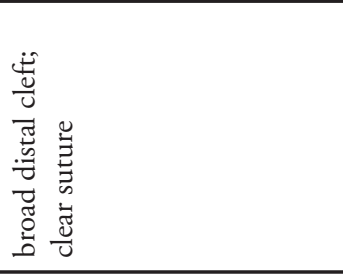 \\
\hline & 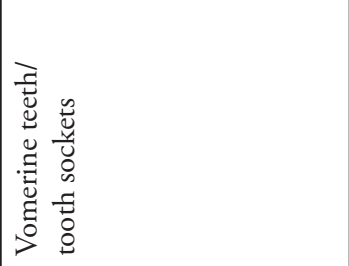 & 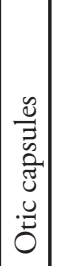 & 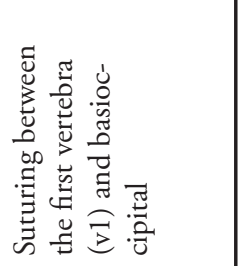 & 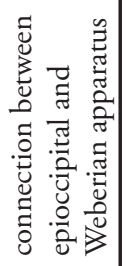 & 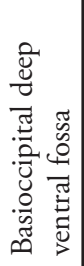 & 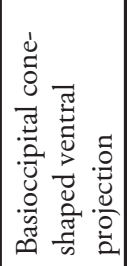 & 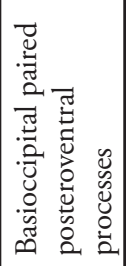 & 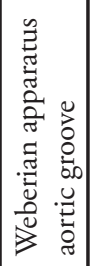 & 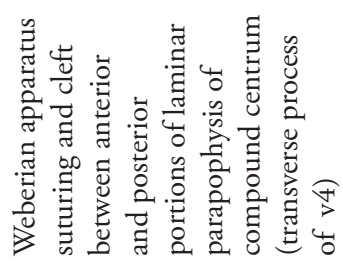 \\
\hline
\end{tabular}

